\title{
WATER, ICE, AND METEOROLOGICAL MEASUREMENTS AT SOUTH CASCADE GLACIER, WASHINGTON, 1996 BALANCE YEAR
}

By Robert M. Krimmel

U.S. GEOLOGICAL SURVEY

Water-Resources Investigations Report 97-4143

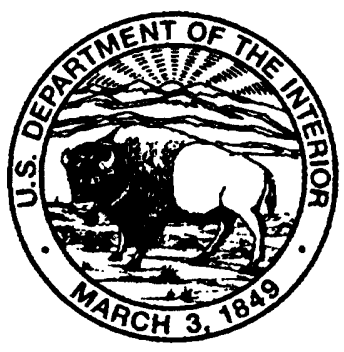




\section{U.S. DEPARTMENT OF THE INTERIOR \\ BRUCE BABBITT, Secretary \\ U.S. GEOLOGICAL SURVEY \\ Gordon P. Eaton, Director}

For additional information write to:

Ice and Climate Project

U.S. Geological Survey

University of Puget Sound

Tacoma, Washington 98416
Copies of this report can

be purchased from:

U.S. Geological Survey

Branch of Information Services

Box 25286

Denver Federal Center

Denver, Colorado 80225 


\section{CONTENTS}

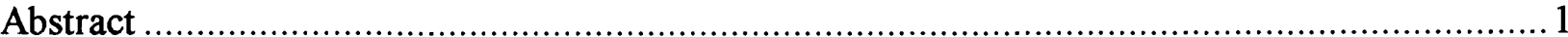

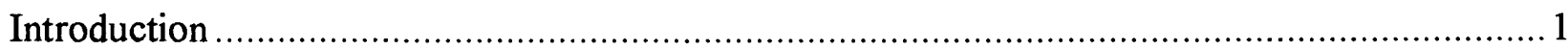

Description and climate of the area ................................................................ 2

Measurement systems ................................................................................ 2

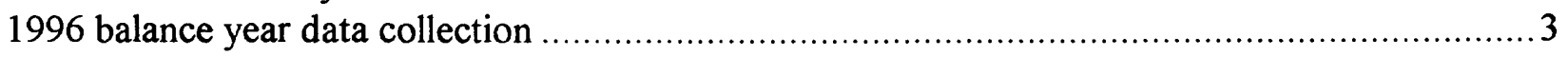

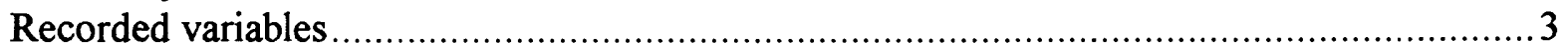

Intermittent measurements ........................................................................ 4

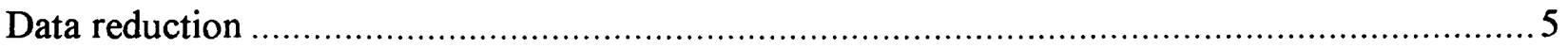

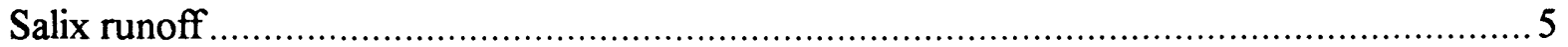

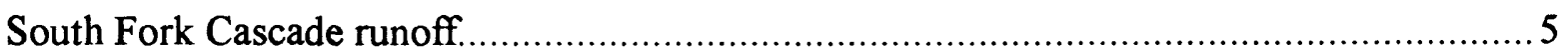

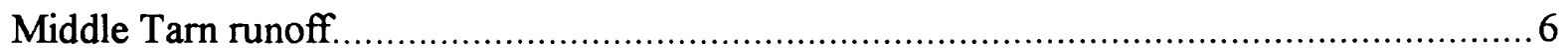

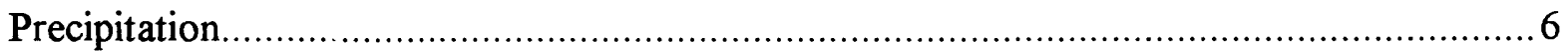

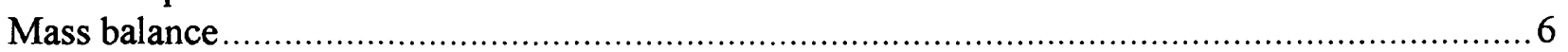

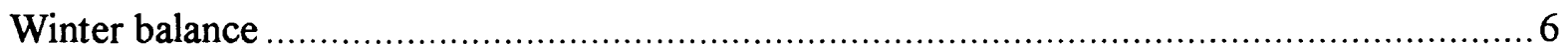

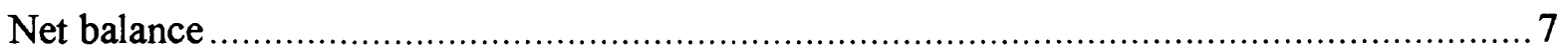

Balance year to water year adjustments ............................................................... 7

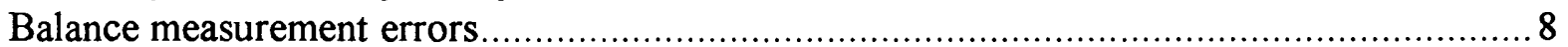

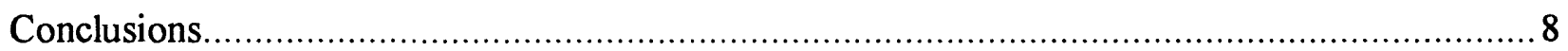

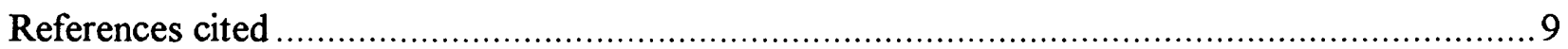

\section{ILLUSTRATIONS}

Figure 1. Map showing South Cascade Glacier and vicinity .............................................. 10

2. Graphs showing air temperature and barometric pressure near South

Cascade Glacier during the 1996 water year..................................................... 11

3. Graphs showing daily precipitation near South Cascade Glacier during

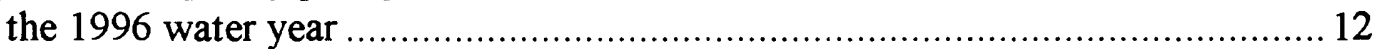

4. Graphs showing river stages near South Cascade Glacier during the 1996

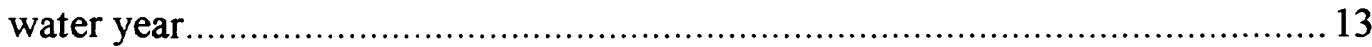

5. Map showing snow depths on South Cascade Glacier on May 24, 1996 .................. 14

6. Graph showing snow depth and firn or ice loss at South Cascade Glacier

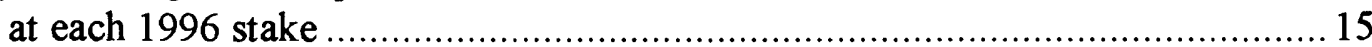

7. Vertical photograph of South Cascade Glacier, September 10, $1996 \ldots \ldots \ldots \ldots \ldots \ldots \ldots . . . . .16$

8. Map showing altitude grid for South Cascade Glacier,

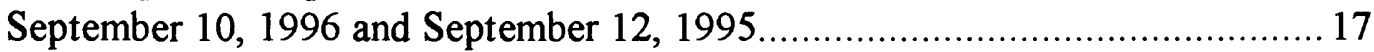

9. Map showing South Cascade Glacier terminus positions, September 12, 1995 and September 10, 1996............................................. 18

10. Graphs showing runoff near South Cascade Glacier during the 1996

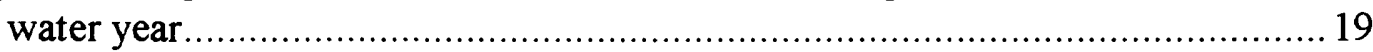

11. Graph showing Middle Tarn and Salix precipitation for 1996 water year .................20 20

12. Graph showing snow depth as a function of altitude at South Cascade Glacier, May 24, 1996

13. Map showing minimum net balances at South Cascade Glacier for 1996 balance year 


\section{ILLUSTRATIONS--Continued}

14. Graph showing net balance as a function of altitude at South Cascade

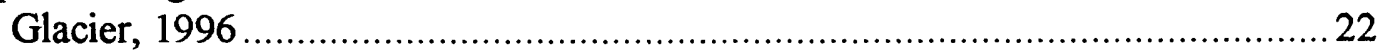

15. Graph showing cumulative net balance at South Cascade Glacier .............................22

16. Graph showing winter, summer, and net mass balances for South

Cascade Glacier, 1953-96.

\section{TABLES}

Table 1. Air temperature at 1,587 meters altitude, Salix Basin, 1996 water year ..................... 24

2. Air temperature at 1,615 meters altitude, South Cascade Glacier Basin,

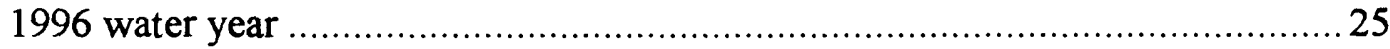

3. Air temperature at 1,631 meters altitude, South Cascade Glacier Basin,

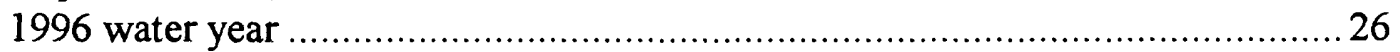

4. Air temperature at 1,848 meters altitude, South Cascade Glacier Basin,

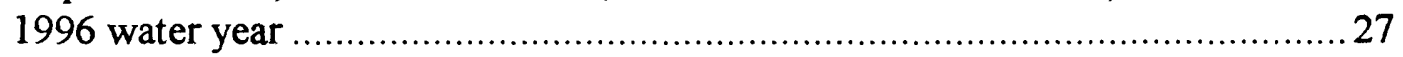

5. Precipitation at 1,587 meters altitude, Salix Basin, 1996 water year ........................22

6. Precipitation at 1,631 meters altitude, Middle Tarn, 1996 water year .......................28

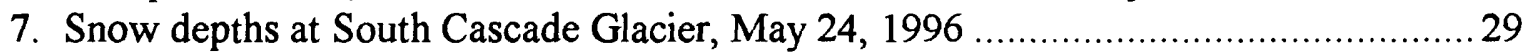

8. Snow density at 1,618 meters altitude, in South Cascade Glacier Basin,

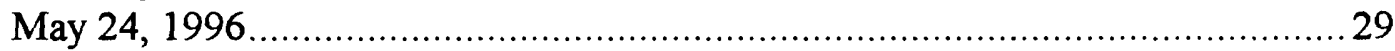

9. Snow density on South Cascade Glacier, at 1,842 meters altitude,

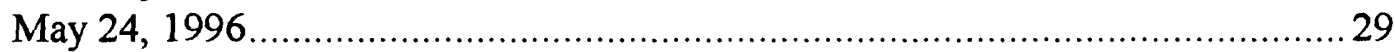

10. Stake and late season core measurements at South Cascade Glacier

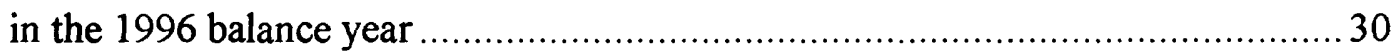

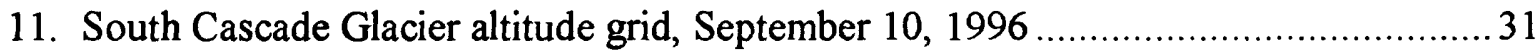

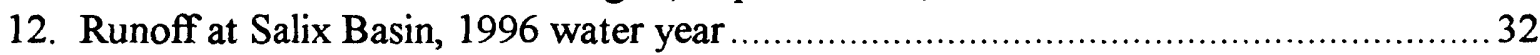

13. Runoff at South Cascade Glacier Basin, 1996 water year........................................ 32

14. Runoff at Middle Tarn Basin, 1996 water year..................................................... 33

15. Values used to interpolate snow depth at any altitude on South

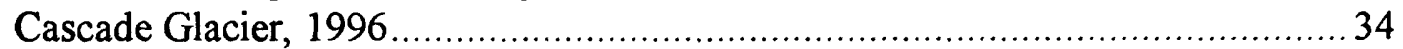

16. Values used to interpolate net balance at any altitude on South

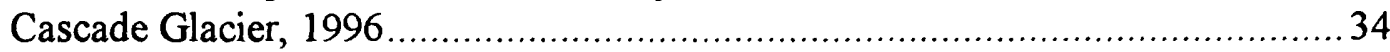




\begin{tabular}{lcl} 
Multiply & By & To obtain \\
\hline degree Celsius $\left({ }^{\circ} \mathrm{C}\right)$ & 1.8, then add 32 & degree Fahrenheit \\
kilogram $(\mathrm{kg})$ & 2.205 & pound \\
kilometer $(\mathrm{km})$ & 0.6214 & mile \\
kilopascal $(\mathrm{kPa})$ & 0.1450 & pound per square inch \\
meter $(\mathrm{m})$ & 3.281 & foot \\
millimeter $(\mathrm{mm})$ & 0.03937 & inch \\
square kilometer $\left(\mathrm{km}^{2}\right)$ & 0.3861 & square mile \\
\hline
\end{tabular}

Vertical datum:

In this report "sea level" refers to the National Geodetic Vertical Datum of 1929 (NGVD of 1929)--a geodetic datum derived from a general adjustment of the first-order level nets of both the United States and Canada, formerly called Sea Level Datum of 1929.

Symbols used in this report:

$\bar{b}_{0}$

$\bar{b}_{1}$

$\bar{b}_{\mathrm{a}}$

$\bar{b}_{\mathrm{m}}(\mathrm{s})$

$\bar{b}_{\mathrm{n}}$

$\bar{b}_{\mathrm{x}}(\mathrm{s})$

$\mathrm{q}$

$\mathrm{S}$

$\mathrm{X}$

$\mathrm{Y}$

Z

The change in balance between the minimum balance near the beginning of the water year and October 1 .

The change in balance between the minimum balance near the end of the water year and September 30.

The change in snow, firn, and ice storage between the beginning and end of some fixed period, which here is the water year.

The snow above the previously formed summer surface as measured directly by field work in late spring as near as possible to the time of greatest glacier mass. The change in snow, firn, and ice storage between times of minimum mass.

The maximum of snow mass during the balance year.

River discharge.

River stage.

Approximate east/west position in the local survey net.

Approximate north/south position in the local survey net.

Altitude above sea level.

Machine-readable files:

Most of the data contained in this report have been recorded on easily copied computer media. This machine-readable material is available from the World Data Center, Campus Box 449, University of Colorado, Boulder, CO 80309. 


\title{
WATER, ICE, AND METEOROLOGICAL MEASUREMENTS AT SOUTH CASCADE GLACIER, WASHINGTON, 1996 BALANCE YEAR
}

\author{
Robert M. Krimmel
}

\begin{abstract}
Winter snow accumulation and summer snow, firn, and ice melt were measured at South Cascade Glacier, Washington to determine the winter and net balances for the 1996 balance year. The 1996 winter balance, averaged over the glacier, was 2.94 meters, and the net balance was 0.10 meter. The winter balance was approximately 0.6 meter greater than the 1977-95 average winter balance (2.30 meters). The net balance, which was positive for the first time since 1984, was more than a meter greater than the 1977-95 average net balance (-0.96 meter). The glacier retreated about 15 meters from its 1995 position. Runoff was measured from the glacier and an adjacent non-glacierized basin. Air temperature, precipitation, and barometric pressure were measured nearby. This report makes these data available to the glaciological and climatological community.
\end{abstract}

\section{INTRODUCTION}

South Cascade Glacier is a small valley glacier near the crest of the North Cascade Range, Washington State (fig. 1). Numerous variables relating to the glacier regime have been measured on and near South Cascade Glacier since the late 1950's. The long-term goal of this project is to understand the climate-glacier relation. A short-term goal is to document the measurements with sufficient detail so that an internally consistent record of conditions on and around the glacier can be assembled despite personnel changes, discontinuous records, and changing methods of data collection and analysis. Some periods of record at South Cascade Glacier have been documented. Work from 1957-64 is described by Meier and Tangborn (1965), work from 1965-67 is described by Meier and others (1971) and by Tangborn and others (1977). Hydrologic and meteorological data for 1957-67 are presented by Sullivan (1994). Mass balance results are summarized by Krimmel (1989) for 1958-85, and are presented in detail for 1992-95 (Krimmel, 1993, 1994, 1995, 1996a). The purpose of this report is to document the measurements of the 1996 balance year that are relevant to the relation between South Cascade Glacier and climate. These measurements include those of basin runoff, precipitation, air temperature, snow thickness and density, ice ablation, and surface altitude.

The mass balance program at South Cascade Glacier is part of a larger U.S. Geological Survey (USGS) effort to monitor glacier mass balance throughout the western states. Mass balance at two other glaciers, Gulkana Glacier and Wolverine Glacier, both in Alaska, is also monitored by the USGS. South Cascade Glacier is considered to be a "benchmark glacier" as described in Fountain and others (1997). 


\section{Description and Climate of the Area}

South Cascade Glacier is located at the head of the South Fork of the Cascade River, a tributary to the Skagit River, which flows into Puget Sound about $100 \mathrm{~km}$ to the west. The region is dominated by steep terrain, with relief of more than $1,000 \mathrm{~m}$. Areas in the basin not covered by glacier ice or water are underlain by bedrock. The bedrock is mantled either by a thin layer of soil and, in places, by scrub conifer, heather, or other vegetation typical of the high North Cascade Range, or is covered by glacial moraine or outwash material.

South Cascade Lake Basin has an area ${ }^{1}$ of $6.14 \mathrm{~km}^{2}$, and spans from 1,615 to $2,518 \mathrm{~m}$ altitude. A sub-basin of the South Cascade Lake Basin is the $4.46 \mathrm{~km}^{2}$ Middle Tarn Basin', which constitutes the southern two-thirds of the South Cascade Lake Basin. Virtually all icemelt ${ }^{3}$ within the South Cascade Lake Basin takes place in the Middle Tarn Basin.

Salix Basin (fig. 1), adjacent to the South Cascade Lake Basin, is predominantly south facing and contains no glacial ice. It has an area ${ }^{4}$ of $0.22 \mathrm{~km}^{2}$ and spans from 1,587 to $2,140 \mathrm{~m}$ altitude.

The climate of the region is maritime. Near the glacier, typical winter low temperatures are about $-10^{\circ} \mathrm{C}$, and typical summer high temperatures are about $20^{\circ} \mathrm{C}$. Most of the precipitation, which commonly reaches $4.5 \mathrm{~m}$ annually (Meier and others, 1971), falls as snow in the period October to May.

\section{Measurement Systems}

Glacier mass balance definitions (Mayo and others, 1972) are adhered to in this report, and the stratigraphic system, which is more field compatible than the fixed date system, is usually used. The specific terms are defined where first used. Other mass balance nomenclatures are in use, notably those described by Østrem and Brugman (1991), which could as well be used to report these results. The definitions by Mayo and others (1972) are used to maintain consistency with earlier reports on South Cascade Glacier work.

The balance year, defined by Mayo and others (1972) as the interval between the minimum glacier mass in one year and the minimum glacier mass the following year, is used when appropriate. The water year (WY) is the interval between October 1 of one year and September 30 of the following year; it is designated by the calendar year in which it ends. Thus, this report spans the time from October 1, 1995 through September 30, 1996.

All local geodetic coordinates are in meters, in which the local $+Y$ axis is approximately true north. Vertical locations are in meters above the National Geodetic Vertical Datum of 1929. Horizontal locations are defined by a local system that can be converted to Universal Transverse

${ }^{1}$ The area of this basin has been previously reported as 6.02 and $6.11 \mathrm{~km}^{2}$. These differences are due to different interpretations of the drainage divide.

2 "Middle Tarn" is an unofficial name.

${ }^{3}$ A small, debris-covered area of perennial ice lies outside of the Middle Tarn Basin.

${ }^{4}$ Salix Basin drainage divides are poorly defined. 
Mercator (UTM) zone 10 coordinates by:

UTM easting $=$ local X $(0.99985)+642,000$

UTM northing $=$ local $\mathrm{Y}(0.99985)+5,355,000$.

Densities are given as a decimal fraction of the density of water, the density of which is considered to be 1,000 kilograms per cubic meter.

\section{BALANCE YEAR DATA COLLECTION}

\section{Recorded Variables}

Several variables are measured continuously: in this report, the records of these variables are truncated to the water year, October 1, 1995 through September 30, 1996. When information concerning these variables is required, but is outside of the WY, the required data are discussed. The continuous measurements may be stored on analog recorders, which give a continuous trace of the variable; on digital recorders, which store either instantaneous values, or for some variables a value that is averaged over some time interval; or are transmitted to Tacoma, Washington with a satellite link using a data collection platform (DCP) near the sensors. Some variables are stored simultaneously on both analog and digital recorders.

Air temperature was measured at the Salix gaging station with a DCP, at the South Fork gaging station with both a DCP and an analog strip chart recorder, at the Middle Tarn gaging station with a DCP, and at the Hut (fig. 1) with a digital recorder. Each of these records is shown graphically (fig. 2). Temperature was sampled once per hour at each station and temperature is estimated to be accurate to $\pm 1^{\circ} \mathrm{C}$. Daily maximum (highest of the 24 hourly readings), minimum (lowest of the 24 hourly readings), and mean temperatures are given in tables 1-4.

Precipitation was measured at Salix and Middle Tarn gaging stations (fig. 3). Tipping bucket gage catch was accumulated for 1 hour and recorded with a DCP. Both gage orifices were $200 \mathrm{~mm}$ in diameter and neither had wind screens. The precipitation gages are sensitive to $0.024 \mathrm{~mm}$ of precipitation. Precipitation is known to vary significantly over short distances, especially in areas of high relief. Wind is also known to influence the catch of precipitation gages. These gages were in operation intermittently over the entire year, but no attempt was made to heat the orifices so that snow would pass to the tipping buckets. No attempt has been made to correct the measured precipitation for any of these influences. Daily total precipitation gage catch is given in tables 5 and 6 .

Salix Creek stage was recorded on a DCP and an analog strip chart. The recorders share a single float-driven stage sensor. South Fork Cascade River stage was digitally recorded, and recorded on an analog strip chart in an independent well. Middle Tarn stage was recorded with a DCP and with a digital recorder. The recorders share a single float-driven stage sensor. These stage records are shown in figure 4 . The stage recorders are sensitive to $\pm 3 \mathrm{~mm}$ and are estimated to be accurate to $\pm 3 \mathrm{~mm}$.

Barometric pressure was recorded at the South Fork gaging station (fig. 2). 


\section{Intermittent Measurements}

Snow depth and density, snow, firn, ice ablation and river discharge measurements are made during site visits several times a year. Instruments and facilities are serviced during these visits as well.

Snow depth was measured by probing at numerous locations on May 24, 1996 (fig. 5, table 7). Snow density was measured with a snow tube along an 8-point snow course near the South Fork gaging station on May 24, 1996 (table 8) and in a snow pit with a coring auger near P-1 (fig. 1) on May 24, 1996 (table 9). The snow density measurements were used to convert the snow depths to water equivalent (WE).

Aluminum stakes with wood bottom plugs, $33 \mathrm{~mm}$ in diameter, were set into firn or ice on May 24, 1996 at the stake 2-96, 3-96, 4-96, and 5-96 locations on the glacier (fig. 1). The level of snow, firn, or ice was recorded at these stake locations several times during the year (table 10, fig. 6). The stake 1 location (fig. 1) was marked and subsequent snow depths were measured by probes at the exact location. Stakes 4-95, 2-95, and 2-94 (fig. 1, table 10) had been set in prior years, but as the seasonal snow melted were recovered and used as measurement sites in 1996.

Aerial photography provided a record of the condition of the glacier on September 10, 1996 (fig. 7). Stereo aerial photography is used to make measurements of the size and shape of the glacier, and location of transient snowlines. A digital elevation model (DEM) of the glacier was formed by photogrammetric measurement of altitude at a regular $100 \mathrm{~m}$ spacing over the area of the glacier. Because it is difficult to make an accurate altitude measurement on a stereo model when the surface is nearly featureless snow, the 1996 DEM was not changed from the 1995 DEM in areas where the glacier was snow-covered ${ }^{5}$. The DEM, the altitudes of which are estimated to be accurate to \pm 1 meter, is shown in figure 8 and table 11. The terminus of the glacier (fig. 9) was delineated from the photographs by measuring the locations of numerous points along the edge of the feature. The location of the points is estimated to be accurate to \pm 1 meter. The area of the glacier near the end of the 1995 balance year was $2.034 \mathrm{~km}^{2}$ (Krimmel, 1996a). Assuming that the area of the glacier south of $Y=3,200 \mathrm{~m}$ is unchanged since 1995 , the area of the glacier near the end of the 1996 balance year was $2.015 \mathrm{~km}^{2}$. The terminal ice retreated from its 1995 position almost everywhere along the terminus, and the retreat from 1995-95 was subjectively averaged to be $15 \mathrm{~m}$ (fig. 9). The end-of-year snow- and ice-covered area within the South Cascade Glacier basin was considerably greater in 1996 than in 1995 because more snow remained at the end of the 1996 balance year. The area of this snow cover was not measured, but is readily seen by comparing the vertical photographs of the glacier in the respective years (for example, Krimmel, 1996a, fig. 7).

\footnotetext{
${ }^{5}$ In a glacier that is truly in equilibrium, the surface altitude does not change annually because submergence (in the accumulation area) and emergence (in the ablation area) offset surficial mass loss and gain. Because South Cascade Glacier gained mass in 1995, the accumulation zone became thicker between 1995 and 1996, thus using the accumulation zone 1995 DEM in 1996 would introduce a standard error, but probably less than 1 meter. These elevations are not used directly in the mass-balance computations.
} 
The transient snowline is clearly visible on the October 9, 1996 oblique photograph (cover), and the position of that transient snowline is shown on figure 1 . Because there was little or no melt after October 9, that snowline is considered to be the equilibrium line. The average altitude of points spaced at regular intervals along the highest snowline is the equilibrium line altitude, $1901 \mathrm{~m}$. The ratio of the accumulation area to the total glacier area was 0.40 in 1996 .

\section{DATA REDUCTION}

\section{Salix Runoff}

Salix Creek stage measurements are converted to instantaneous discharge values through use of a stage-discharge rating equation. Instantaneous discharge values are averaged for each day and converted to a basin-averaged daily runoff (fig. 10, table 12). The stage-discharge rating at Salix Creek is controlled by a weir supported by bedrock and no visible changes occurred during the year, thus the rating curve used to convert stage to discharge was the same that has been used since the measurements began in 1960:

$$
\mathrm{q}=\mathrm{S}^{2.57} * 2.71
$$

where $\mathrm{q}$ is discharge in cubic feet per second and $\mathrm{S}$ is stage in feet. The Salix well was frozen briefly in December, and again in January and February, resulting in lost record. (Equations for the rating curves are given in English units for the convenience of the author and reader, as the original stage data are in feet and the machine-readable files are in feet. Except in these two instances, stage has been converted to meters).

\section{South Fork Cascade Runoff}

South Fork stage measurements are similarly converted to instantaneous discharge values, which are averaged for each day and converted to a basin-averaged daily runoff (fig. 10, table 13). The controlling weir is built on glacial outwash and moraine material and is known to be unstable. Visual inspection of the weir and surrounding foundation and diversion walls indicated that changes did occur in 1996, but the two discharge measurements made in 1996 did not justify a new rating curve for 1996. The rating curve used to convert stage to discharge was that used in 1995.

For stage below 0.87 feet:

$$
q=0.0036+5.62 * S-5.57 * S^{2}+14.74 * S^{3}
$$

For stage above 0.86 feet:

$$
q=17.45-43.14 * S+40.94 * S^{2}-0.90 * S^{3}
$$

The South Fork gage instrumentation failed in early November until mid-February, and again briefly during May, resulting in lost record. Because of suspected changes in the control during the year, the errors in the South Fork discharge calculations may be \pm 20 percent of the calculated daily values. 


\section{Middle Tarn Runoff}

At Middle Tarn, stage measurements were converted to discharge (fig. 10, table 14), using a rating equation determined from 14 discharge measurements made between September 8, 1992 and September 16, 1994. The outlet from Middle Tarn is a bedrock channel that does not change; therefore, the rating curve is expected to remain stable. For a stage of 0.35 feet and below,

$$
q=S^{1.809} * 25.123 \text {, }
$$

and at a stage above 0.35 feet,

$$
q=2.064-3.673 * S+24.770 * S^{2}
$$

The Middle Tarn well was frozen from early December until mid-May resulting in lost record.

\section{Precipitation}

The Salix and Middle Tarn precipitation gages were in operation during all of WY 1996. Incremental precipitation was accumulated for each day, and the daily total precipitation is shown graphically in figure 3 , and in tables 5 and 6.

Middle Tarn and Salix daily total precipitation measurements are cross correlated in figure 11 , which indicates that precipitation is slightly greater at Salix, and that precipitation is often very different between the two sites. Salix may only appear to be wetter because it is normally warmer at Salix than at Middle Tarn, and rain is more reliably measured than snow. Neither precipitation measurement site is considered to be necessarily representative because of local variations in precipitation, the difficulty of measuring precipitation when it is windy, or when the precipitation occurs as snow.

\section{MASS BALANCE}

\section{Winter Balance}

Weather in May of 1996 was cloudy, with frequent precipitation, and access to the glacier was difficult. The glacier was visited briefly on May 21, and again on May 24 when most of the snow measurements were made.

Snow density and depth were measured at the P-1 (fig. $1 ; 1,842 \mathrm{~m}$ altitude) index station; a pit was dug through the upper $1.34 \mathrm{~m}$ of snow, and a coring auger was used below that depth. The entire snowpack was isothermal. Total snow depth at the density measurement site was 5.90 $\mathrm{m}$, and bulk density was 0.504 , for a water equivalent (WE) of $2.98 \mathrm{~m}$. The core was continued an additional $0.34 \mathrm{~m}$ into the previous year's material, which had a density of 0.89 . Stake 2-96 was set into the resulting hole.

Snow density was measured near the South Fork gaging station at the $1,618 \mathrm{~m}$ altitude at three places along a snow course. Average bulk density was 0.55 , and the average of eight depth measurements was $1.52 \mathrm{~m}$, for a WE at the snow course of $0.84 \mathrm{~m}$. 
Snow depths were measured at numerous other places on the glacier (fig. 5) using a probe rod. Probing was easy over the entire glacier and almost no ice layers existed in the 1996 snowpack. The buried 1995 summer surface was unambiguous, and could be identified as an impenetrable surface under a few centimeters of soft depth hoar. Probe locations were determined with a non-differential Global Positioning System unit (GPS) coded to allow maximum resolution of the system. The GPS usually indicated $a \pm 20 \mathrm{~m}$ error. Altitude of the probe locations (fig. 5) was recorded by the GPS, and was also measured photogrammetrically (at the GPS-derived location) on the 1995 stereo models. The GPS and stereo model-derived altitudes always agreed within $10 \mathrm{~m}$, and the stereo model altitudes were used for balance calculations.

The measured snow depths were plotted with their respective altitudes (fig. 12), and a curve was hand-drawn through those measured points. Points along the hand-drawn curve (table 15) were used to interpolate a snow depth at each of the 201 grid points of the $1995 \mathrm{DEM}$. A linear relation between the two measured densities was used to determine the density at each DEM grid point, which, when multiplied by the snow depth, was the balance at the grid point. The average of the grid point balances is the measured winter snow balance, $\bar{b}_{\mathrm{m}}(\mathrm{s}), 2.94 \mathrm{~m} \mathrm{WE}$.

The maximum winter snow balance for 1996 was assumed to be equal to the winter snow balance measured during late May, $\bar{b}_{\mathbf{x}}(\mathbf{s})$. Often, winter snow balance is adjusted by considering spring runoff, temperature, and precipitation, but snow conditions during spring 1996 indicated that such an adjustment was unnecessary.

\section{Net Balance}

On September 10, 1996, cores were taken at stake 1 and several other locations in the accumulation area (fig. 13). Ablation continued after September 10, and these measurements were adjusted to a minimum balance value (table 10) at each point using measurements at stakes 1,2 and 4 on October 9, 1996, when there was no fresh snow on the glacier. The final visit to the glacier in 1996 was on October 30 after up to a meter of fresh snow covered the glacier. Measurements to the summer ablation surface on October 30 indicated that very little ablation took place after October 9 . The minimum balance values are plotted against their respective altitudes (fig. 14). A hand-drawn smoothed curve through the points was used to develop a table for interpolating balance at any altitude (table 16). The grid-index method used for the winter balance calculation and in prior South Cascade balance reports (Krimmel 1996b) is also used to calculate the 1996 balance year net balance, $\bar{b}_{\mathrm{n}}$, for South Cascade Glacier of $0.10 \mathrm{~m}$.

\section{Balance Year to Water Year Adiustments}

The final balance increment, $\bar{b}_{1}$, for the 1995 balance year was estimated at $-0.05 \mathrm{~m} \mathrm{WE}$ (Krimmel, 1996a). This value is the initial balance increment, $\bar{b}_{0}$, of the 1996 balance year.

Above-freezing temperatures dominated in early October 1996. Rain fell on October 4-5, then dry mild conditions dominated until October 11 . Rain began on October 11 , and by October 13 below-freezing temperatures were recorded at all stations, and snow covered the entire glacier. 
The storm of October 11-15, 1996 ended the 1996 balance year. The last balance measurements of the 1996 balance year were on October 9,1996 . Ablation between October 1 and 11 was estimated from the precipitation, temperature and runoff records to have averaged $0.15 \mathrm{~m}$ over the glacier area. The final balance increment, $\bar{b}_{1}$, is thus $-0.15 \mathrm{~m}$.

The annual balance, $\bar{b}_{\mathrm{a}}$, is defined by Mayo and others (1972) as the change in snow, firn, and ice storage between the beginning and end of a fixed period, which here is the water year. The measured values of $\bar{b}_{0}, \bar{b}_{1}$, and $\bar{b}_{\mathrm{n}}$ at South Cascade Glacier for the 1996 balance year can be used to derive the annual balance, $\bar{b}_{\mathrm{a}}$, where $\bar{b}_{\mathrm{a}}=\bar{b}_{\mathrm{n}}+\bar{b}_{0}-\bar{b}_{1}=0.20 \mathrm{~m}$.

\section{Balance Measurements Errors}

Errors in glacier balance measurements are difficult to quantify. In prior years of balance measurements at South Cascade Glacier, error values ranging around $0.10 \mathrm{~m}$ were placed on the balance values (Meier and others, 1971). For 1965 and 1966, more information was used to derive the balances than in 1992-96. The availability of less information in 1996 would suggest that greater errors should be assigned to the 1996 balance. This relative paucity of data for 1996 is offset somewhat, however, by the experience gained since the mid-1960's, when 20-30 ablation stakes were used and it was found that spatial variations in balance were similar from year to year (Meier and Tangborn, 1965). Estimated errors are $\bar{b}_{\mathrm{m}}(\mathrm{s}), \bar{b}_{\mathrm{x}}(\mathrm{s})$, and $\bar{b}_{\mathrm{n}}, \pm 0.20 \mathrm{~m} ; \bar{b}_{0}$ and $\bar{b}_{1}$, $\pm 0.05 \mathrm{~m}$; and the calculated error for $\bar{b}_{\mathrm{a}}$ is $\pm 0.21 \mathrm{~m}$. Although other factors that affect the balance, such as internal accumulation of ice, superimposed ice, internal melt, and basal melt, are possible, they are not considered in this report. These unknowns are thought to be small and do not change the error estimations.

\section{CONCLUSIONS}

In 1996, South Cascade Glacier had a positive net balance for the first time since 1984, though the $0.10 \mathrm{~m}$ net balance cannot by itself be construed as a reversal of the trend of negative balances beginning in 1977. The balance record since 1958 (figs. 15 and 16) shows a long-term negative trend, except for a few years in the early to mid-1970's, when there were several strong positive years. After 1976, nearly all years have shown mass loss. The 1996 winter balance was $0.6 \mathrm{~m}$ greater than the $1977-95$ average winter balance of $2.30 \mathrm{~m}$, and the 1996 net balance was $1.0 \mathrm{~m}$ greater than the $1977-95$ average net balance of $-0.96 \mathrm{~m}$, suggesting that the summer of 1996 was the dominating influence toward a "healthy" glacier. Despite the positive net balance, the glacier retreated about $15 \mathrm{~m}$ between 1995 and 1996. 


\section{REFERENCES CITED}

Fountain, A.G., Krimmel, R.M., and Trabant, D.C., 1997, A strategy for monitoring glaciers: U.S. Geological Survey Circular 1132, 19 p.

Krimmel, R.M., 1989, Mass balance and volume of South Cascade Glacier, Washington, 1958-1985, in Oerlemans, J., ed., Glacier fluctuations and climatic change: Dordrecht, Netherlands, Kluwer Academic Publishers, p. 193-206.

1993, Mass balance, meteorological, and runoff measurements at South Cascade Glacier,

Washington, 1992 balance year: U.S. Geological Survey Open-File Report 93-640, 38 p.

----- 1994, Runoff, precipitation, mass balance, and ice velocity measurements at South Cascade Glacier, Washington, 1993 balance year: U.S. Geological Survey Water-Resources Investigations Report 94-4139, 35 p.

-.--- 1995, Water, ice, and meteorological measurements at South Cascade Glacier, Washington, 1994 balance year: U.S. Geological Survey Water-Resources Investigations Report 95-4162, $41 \mathrm{p}$.

1996a, Water, ice, and meteorological measurements at South Cascade Glacier, Washington, 1995 balance year: U.S. Geological Survey Water-Resources Investigations Report 96-4174, $37 \mathrm{p}$.

----- 1996b, Glacier mass balance using the grid-index method, in Colbeck, S.C., ed., Glaciers, ice sheets and volcanoes: A tribute to Mark F. Meier: Cold Regions Research Engineering Laboratory Special Report 96-27, p. 62-68.

Mayo, L.R., Meier, M.F., and Tangborn, W.V., 1972, A system to combine stratigraphic and annual mass-balance systems--A contribution to the International Hydrological Decade: Journal of Glaciology, v. 11, no. 61, p. 3-14.

Meier, M.F., and Tangborn, W.V., 1965, Net budget and flow of South Cascade Glacier, Washington: Journal of Glaciology, v. 5, no. 41, p. 547-566.

Meier, M.F., Tangborn, W.V., Mayo, L.R., and Post, Austin, 1971, Combined ice and water balances of Gulkana and Wolverine Glaciers, Alaska, and South Cascade Glacier, Washington, 1965 and 1966 water years: U.S. Geological Survey Professional Paper 715-A, $23 \mathrm{p}$.

Østrem, G., and Brugman, M., 1991, Glacier mass-balance measurements--A manual for field and office work: National Hydrology Research Institute Science Report No. 4, 224 p.

Sullivan, M.E., 1994, South Cascade Glacier, Washington--Hydrologic and meteorological data, 1957-67: U.S. Geological Survey Open-File Report 94-77, 105 p.

Tangborn, W.V., Mayo, L.R., Scully, D.R., and Krimmel, R.M., 1977, Combined ice and water balances of Maclure Glacier, California, South Cascade Glacier, Washington, and Wolverine and Gulkana Glaciers, Alaska, 1967 water year: U.S. Geological Survey Professional Paper 715-B, $20 \mathrm{p}$. 


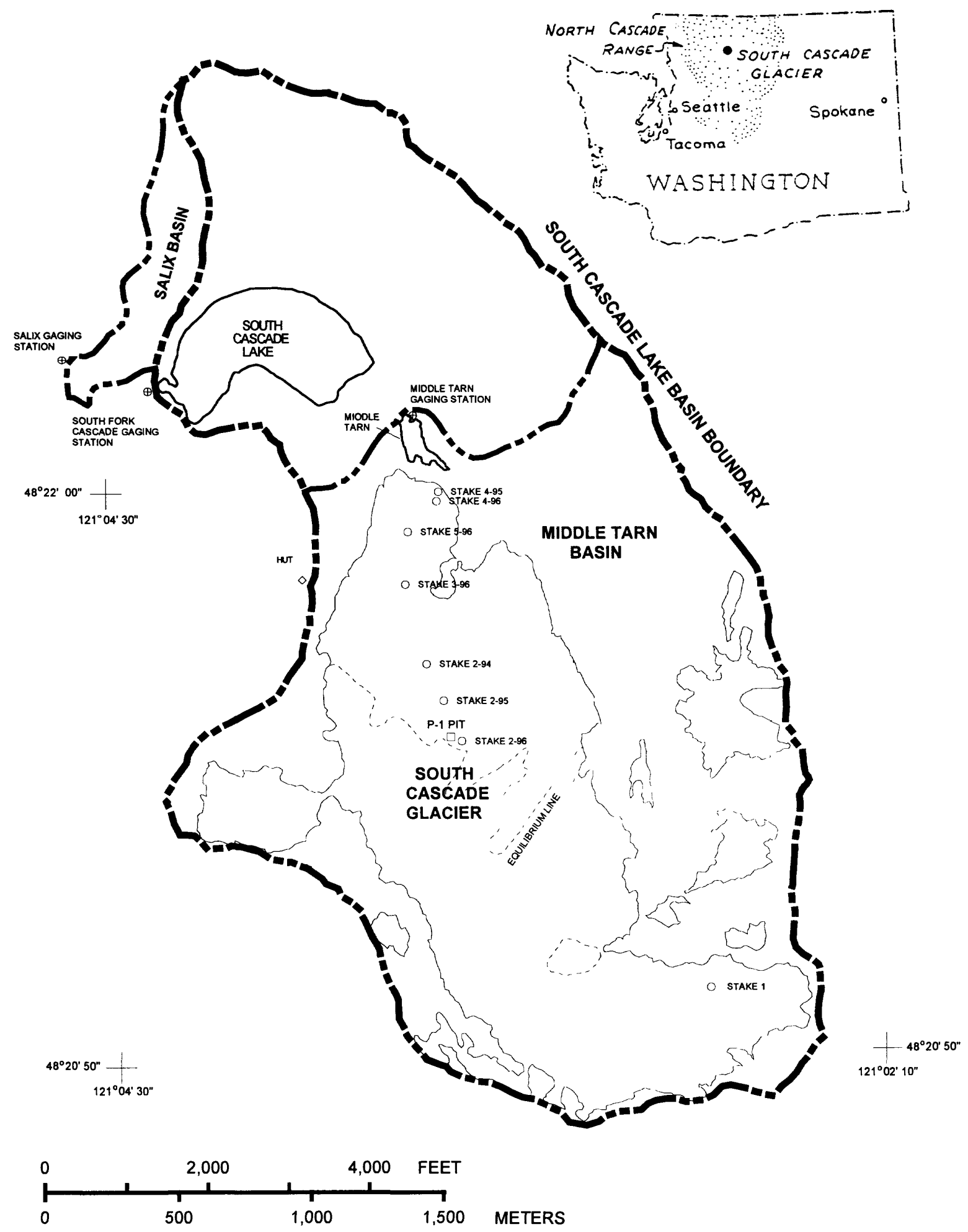

FIGURE 1. South Cascade Glacier and vicinity. 

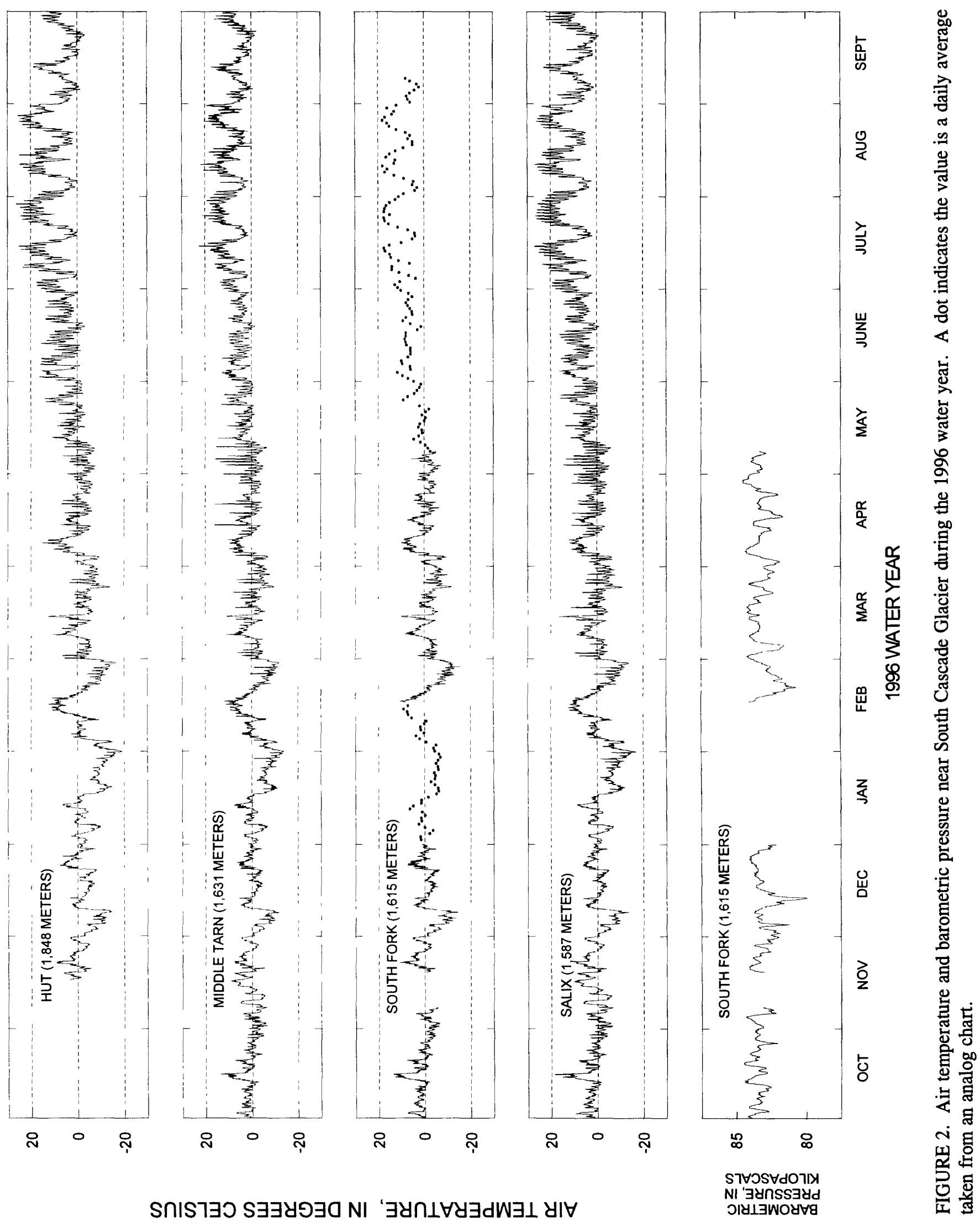


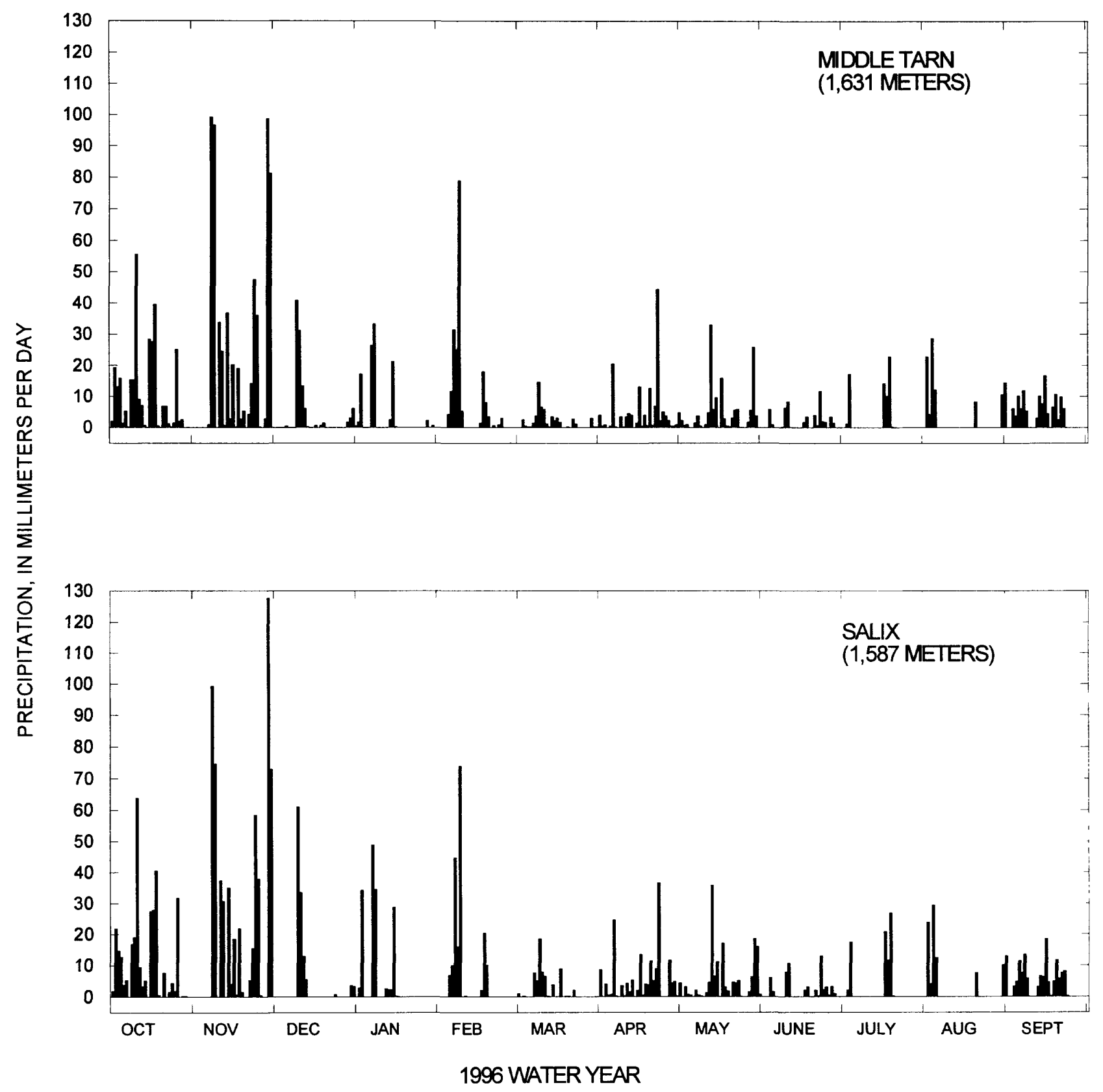

FIGURE 3. Daily precipitation (gage catch) near South Cascade Glacier during the 1996 water year. 

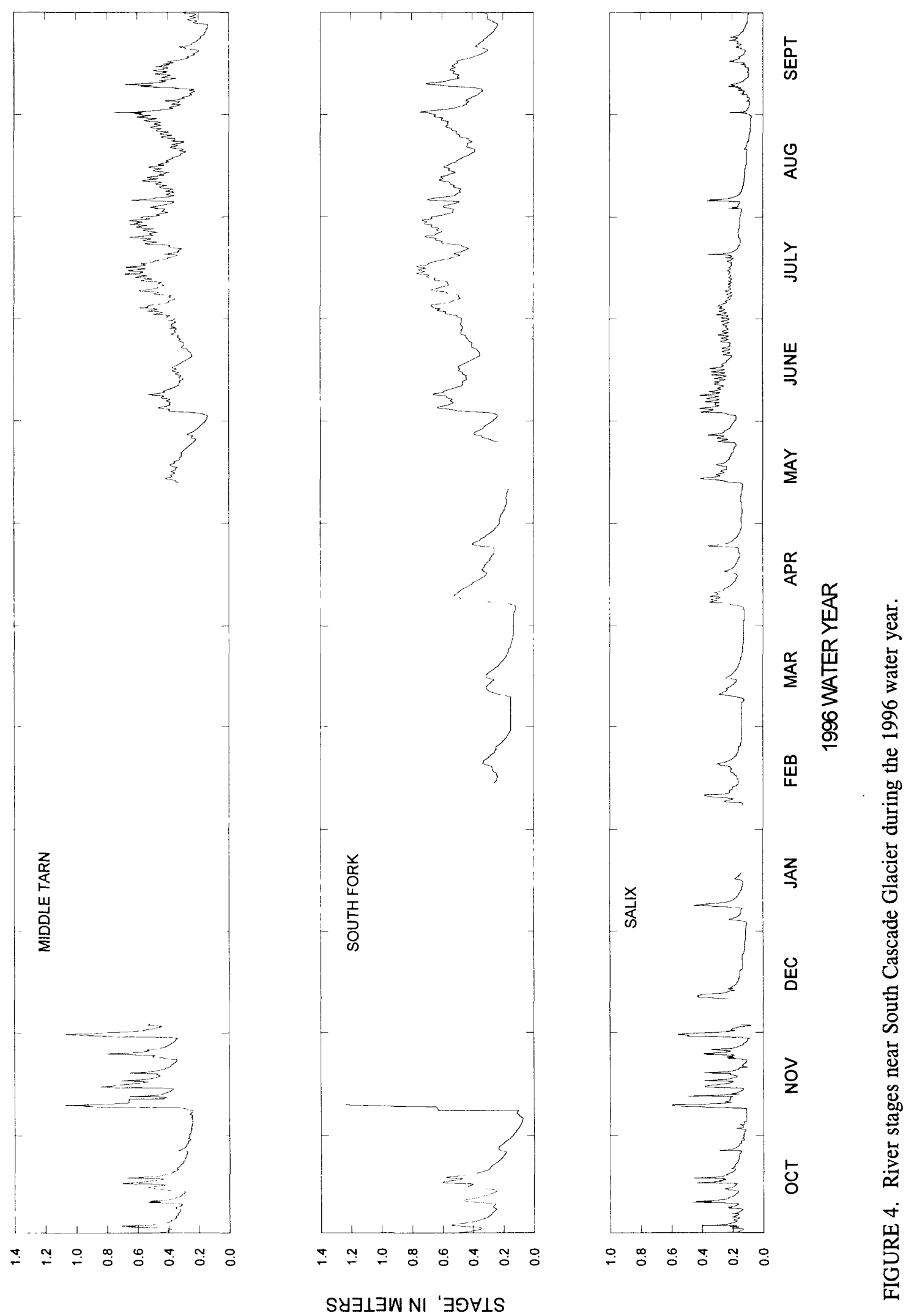


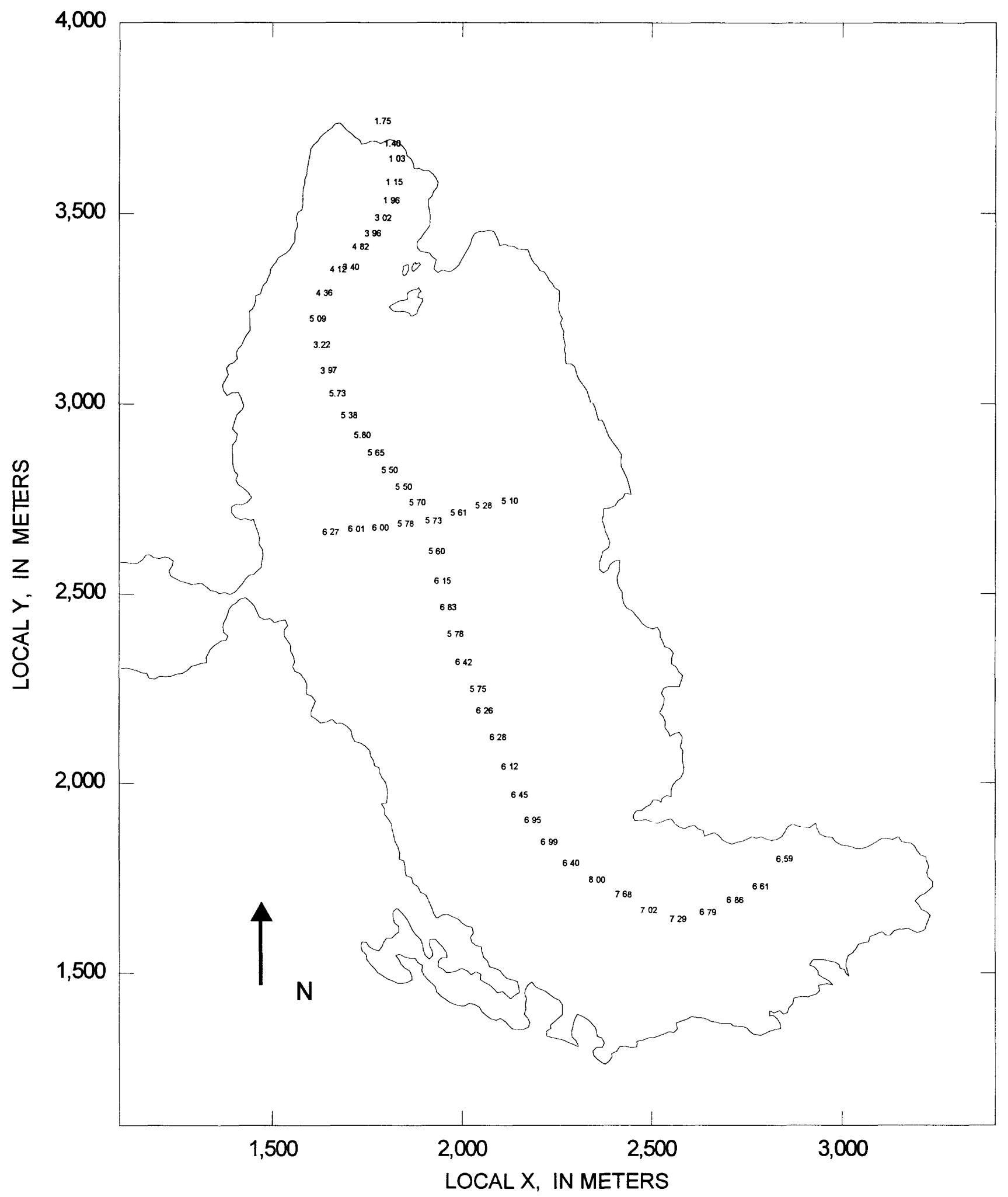

FIGURE 5. Snow depths, in meters, on South Cascade Glacier on May 24, 1996. 


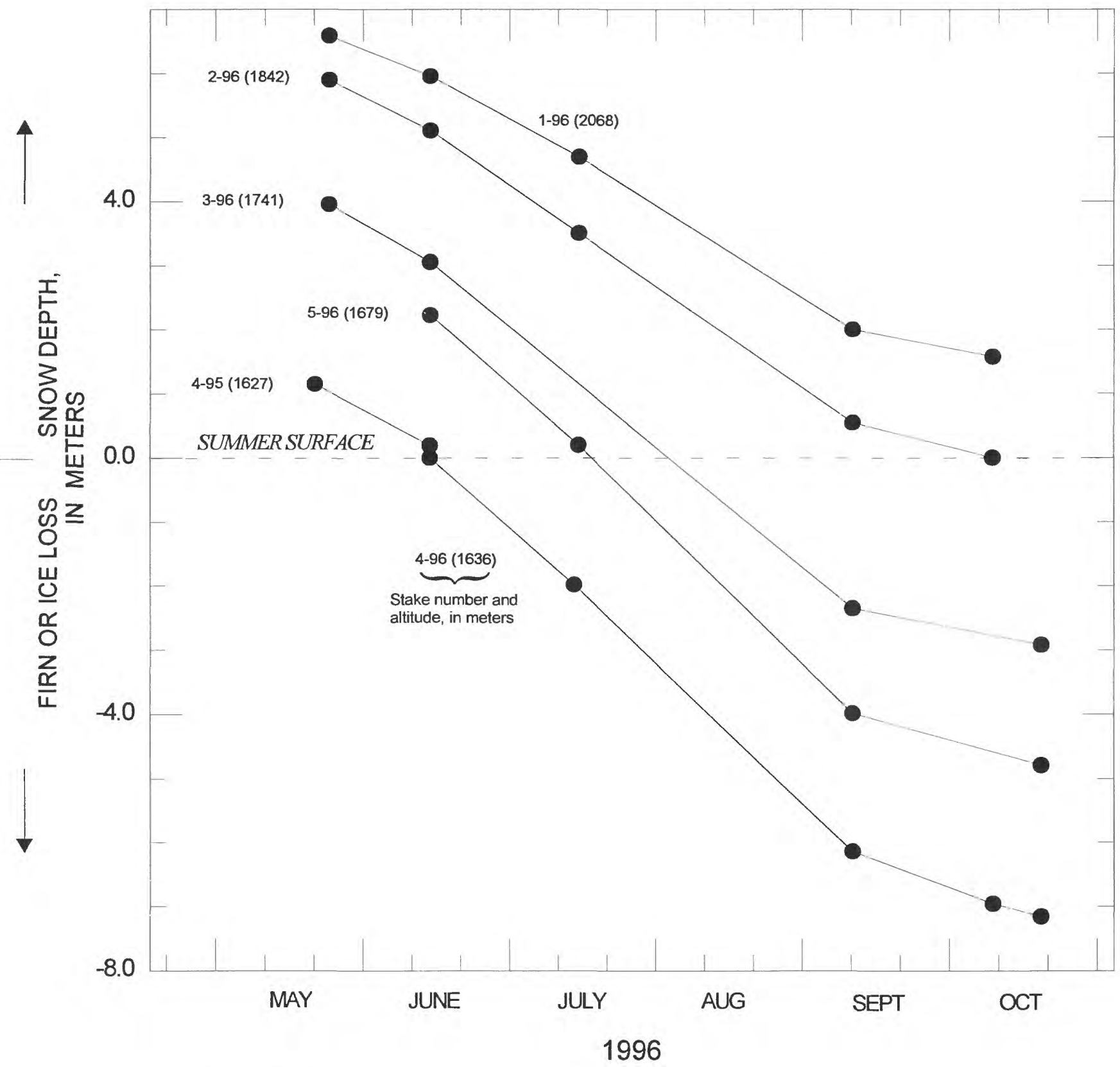

FIGURE 6. Snow depth and firn or ice loss at South Cascade Glacier at each 1996 stake. Depths are accurate to 0.1 meter. 


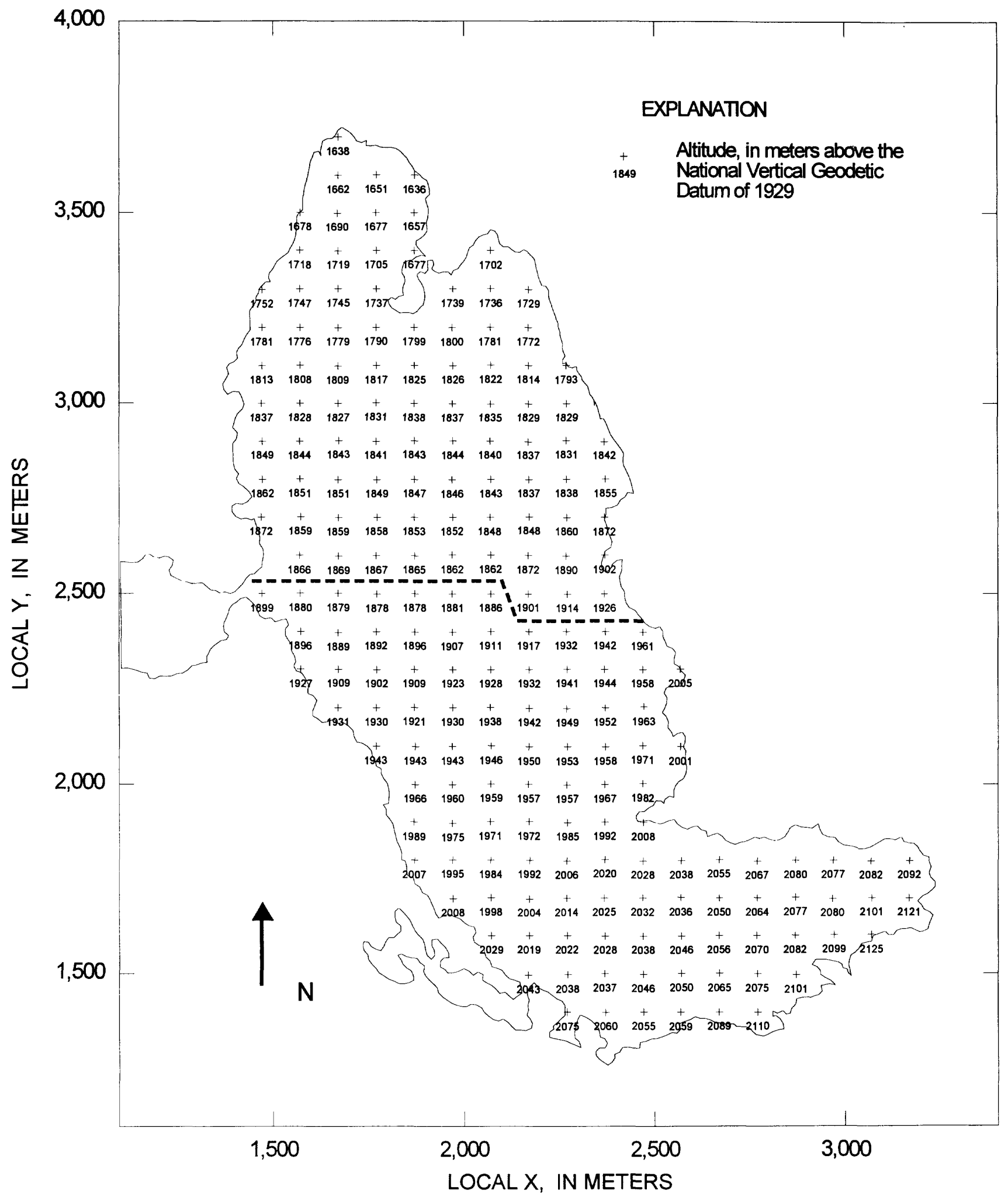

FIGURE 8. Altitude grid for South Cascade Glacier, measured from stereo vertical photographs taken on September 10, 1996 (north of dashed line) and September 12, 1995 (south of dashed line). 


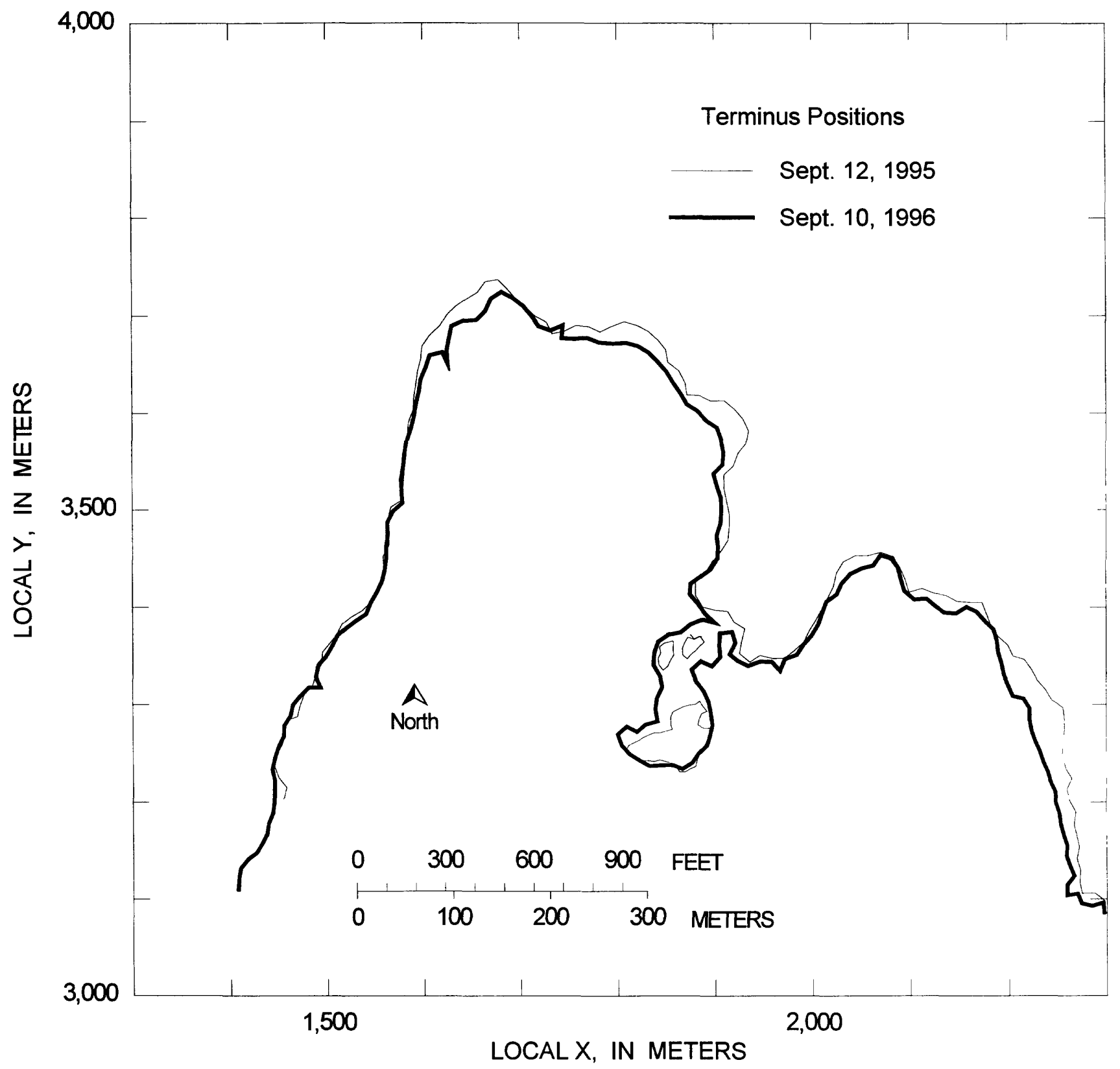

FIGURE 9. South Cascade Glacier terminus positions for September 12, 1995, and September 10, 1996. 

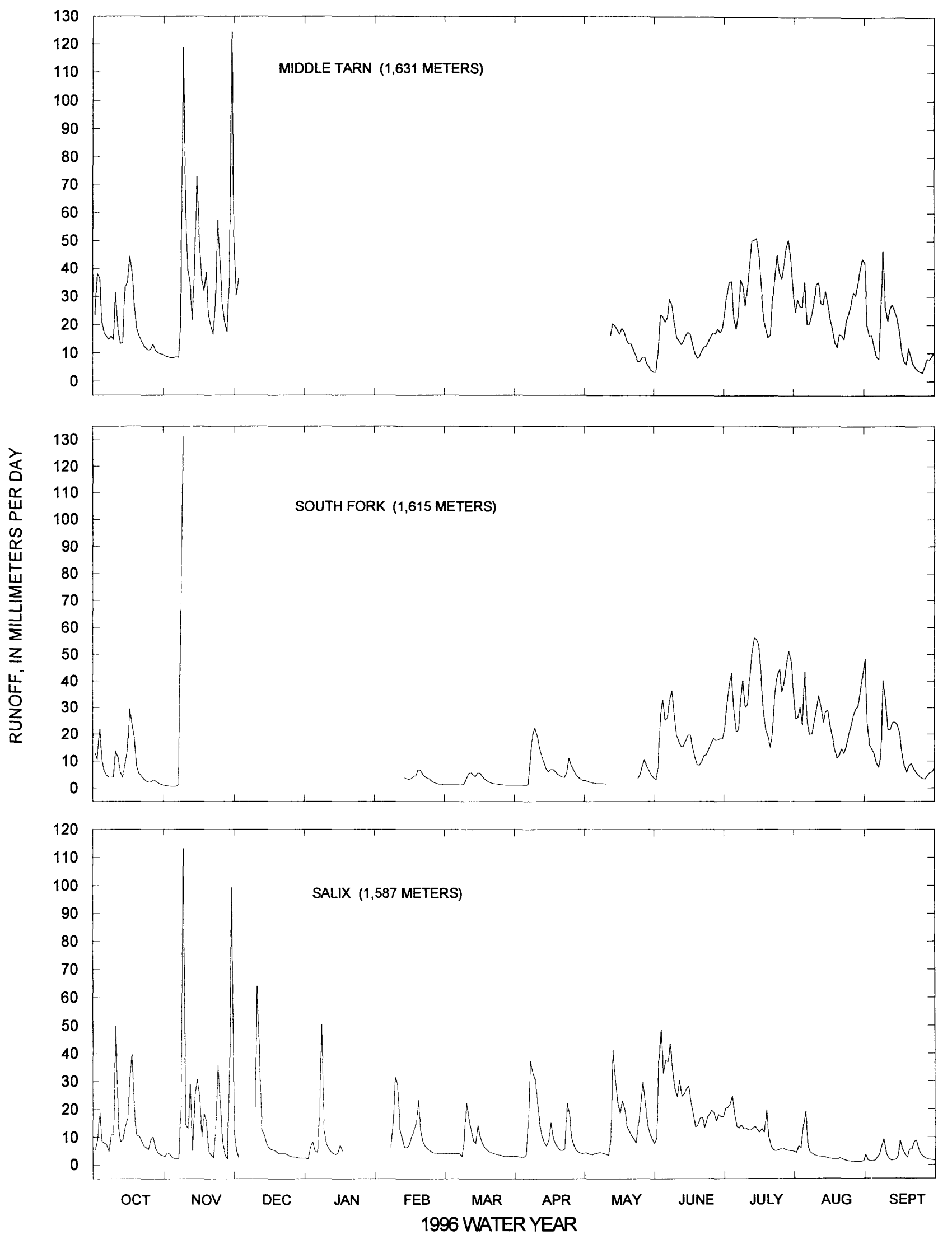

FIGURE 10. Runoff near South Cascade Glacier during the 1996 water year. 


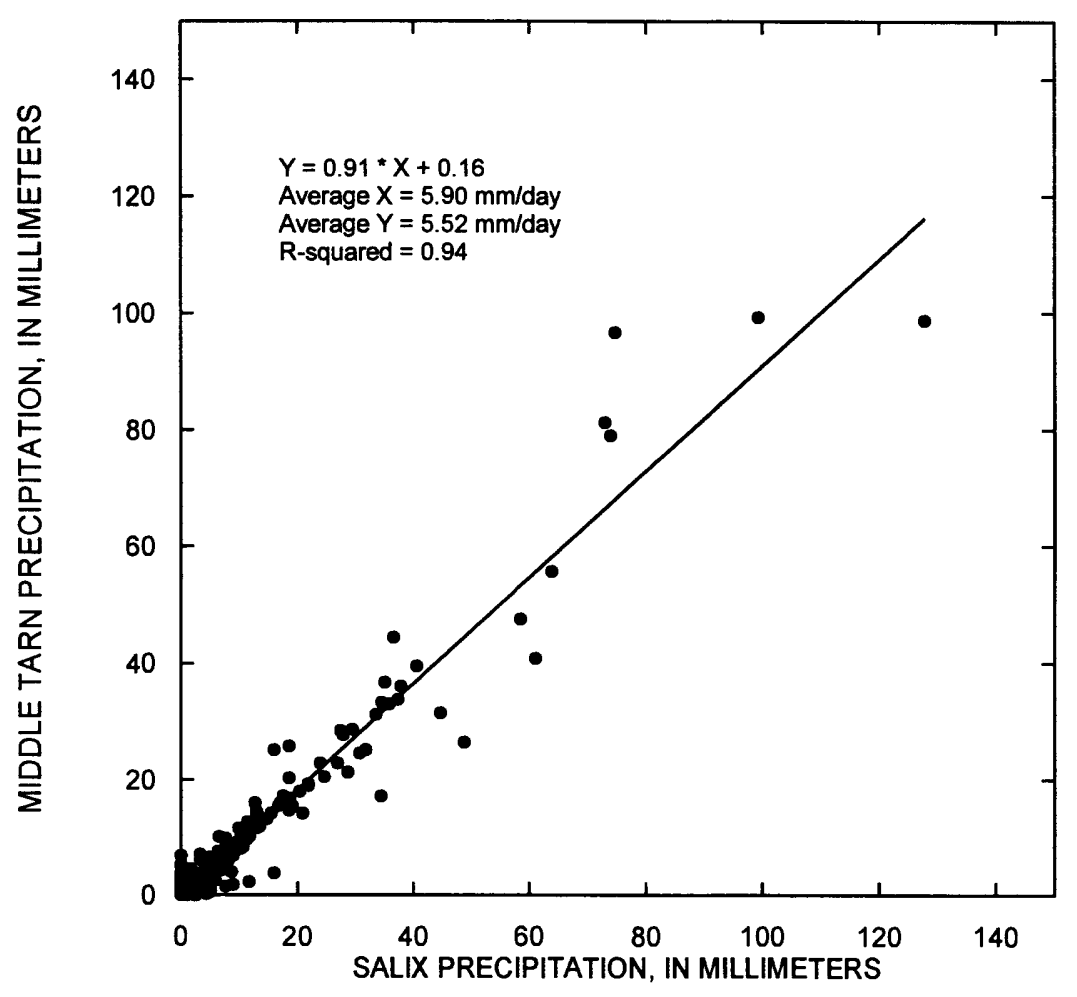

FIGURE 11. Middle Tarn and Salix precipitation for the 1996 water year.

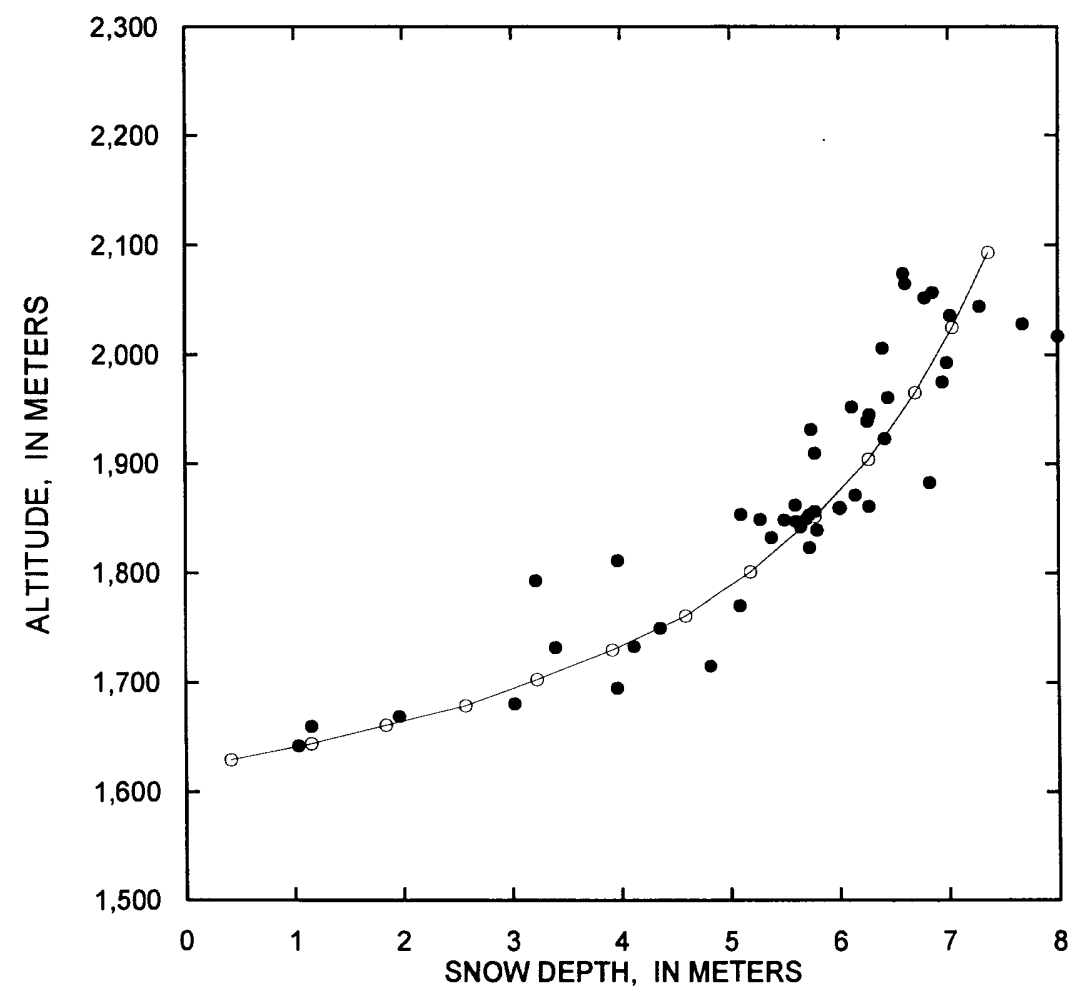

FIGURE 12. Snow depth as a function of altitude at South Cascade Glacier, May 24, 1996. Solid circles are measured, open circles are points along a hand-drawn curve used for interpolation. 


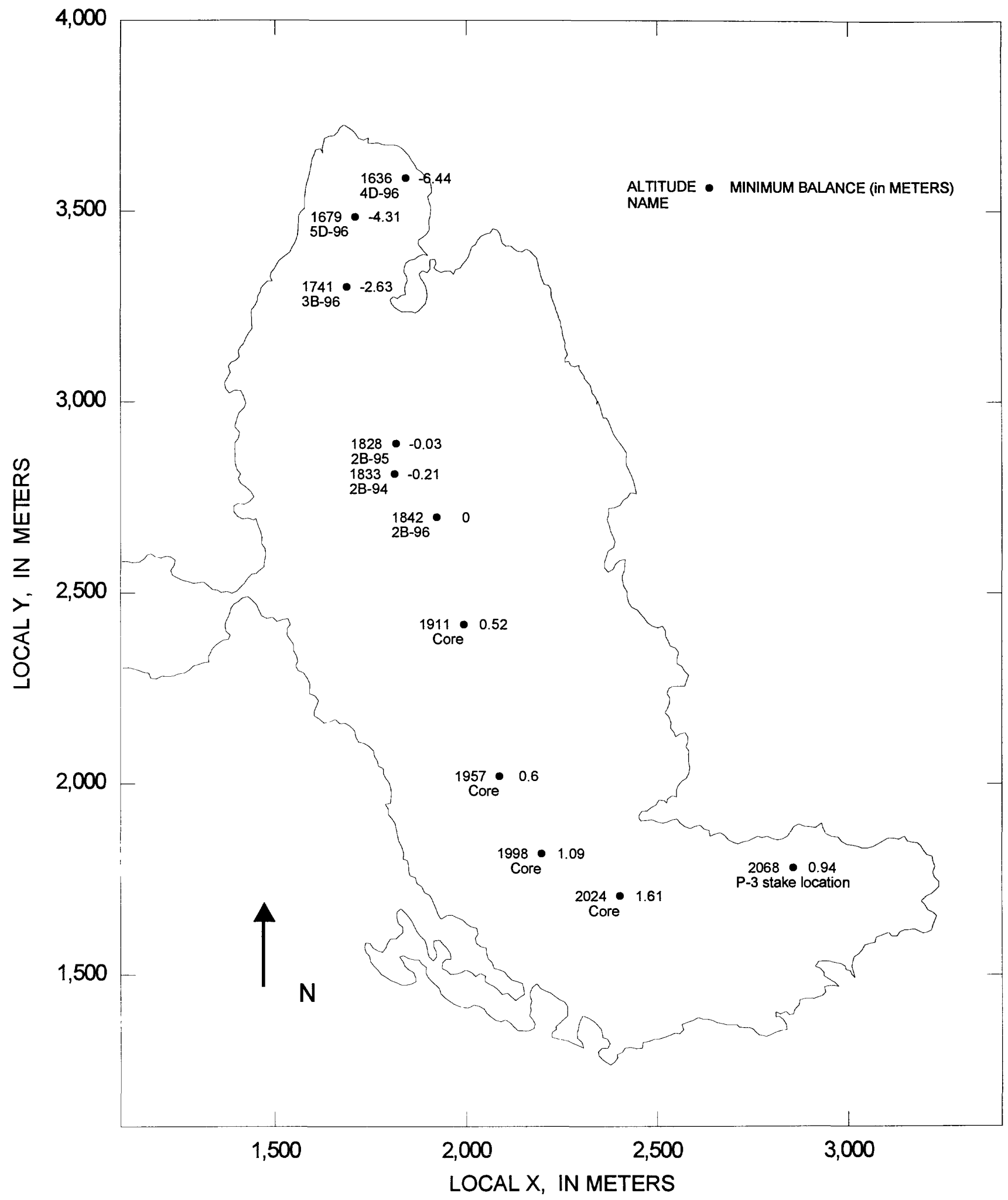

FIGURE 13. Minimum net balances at South Cascade Glacier for the 1996 balance year. 


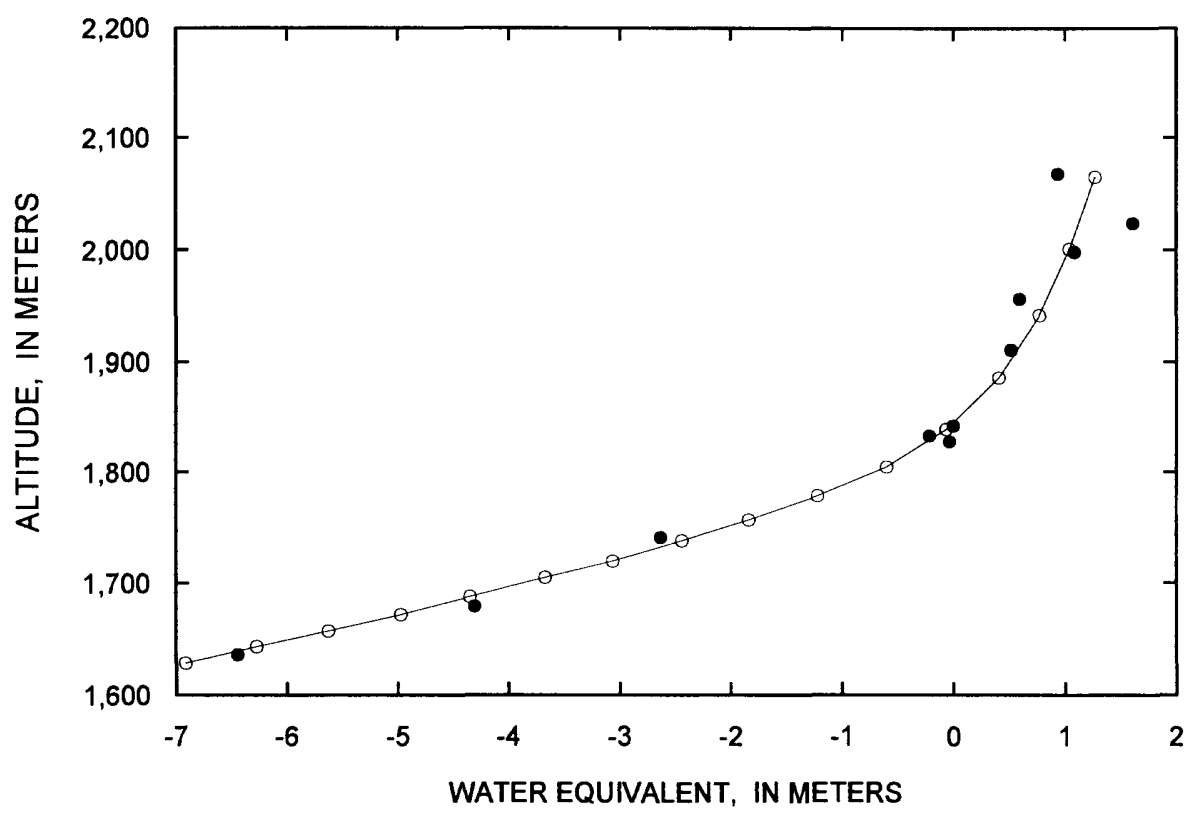

FIGURE 14. Net balance as a function of altitude at South Cascade Glacier, 1996. Solid circles are measured, open circles are along a hand-drawn curve used for interpolation.

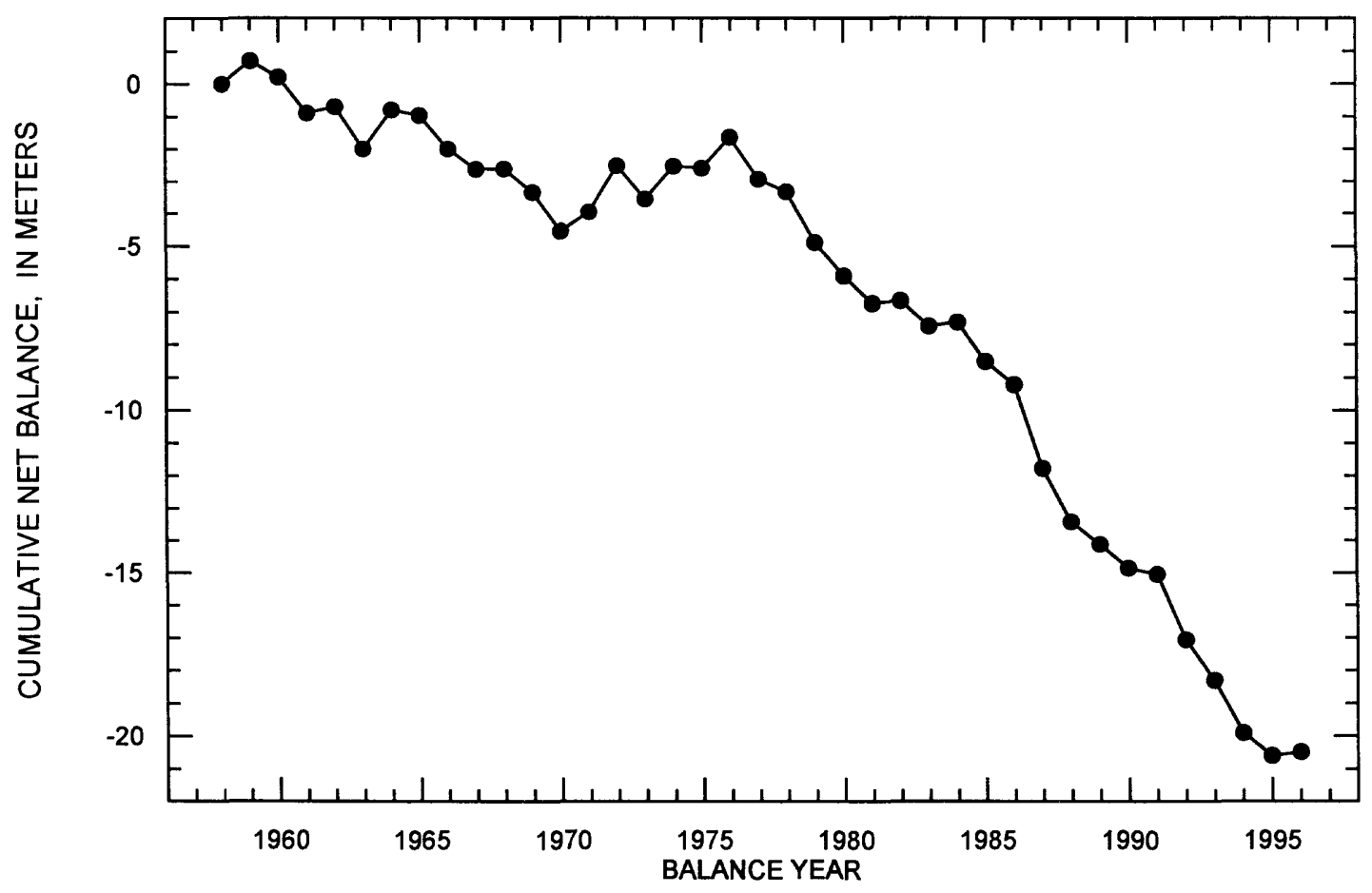

FIGURE 15. Cumulative net balance at South Cascade Glacier. 


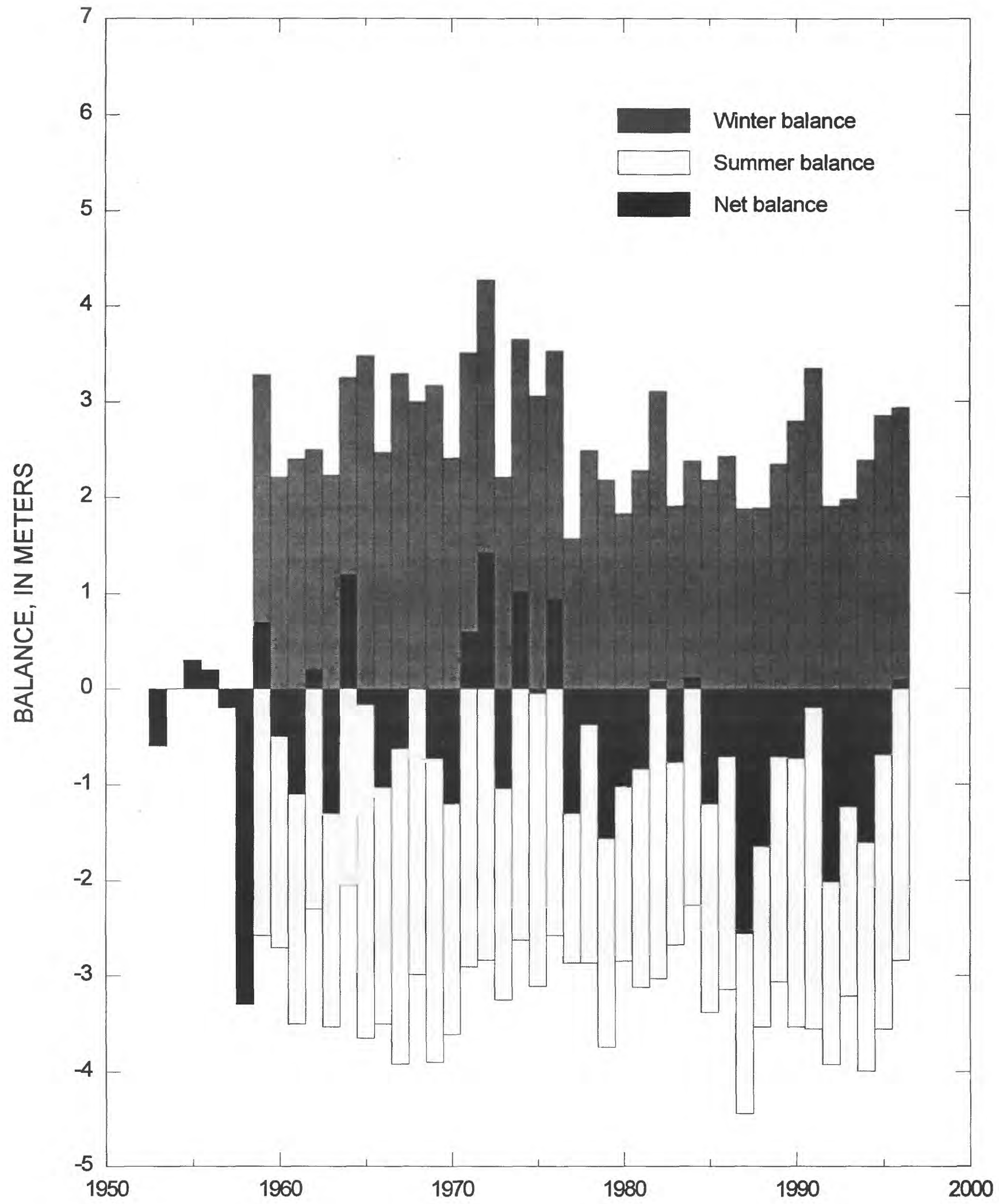

FIGURE 16. Winter, summer, and net mass balances for South Cascade Glacier, 1953-96. Data from Meier and Tangborn (1965) and Krimmel (1995, 1996a). 


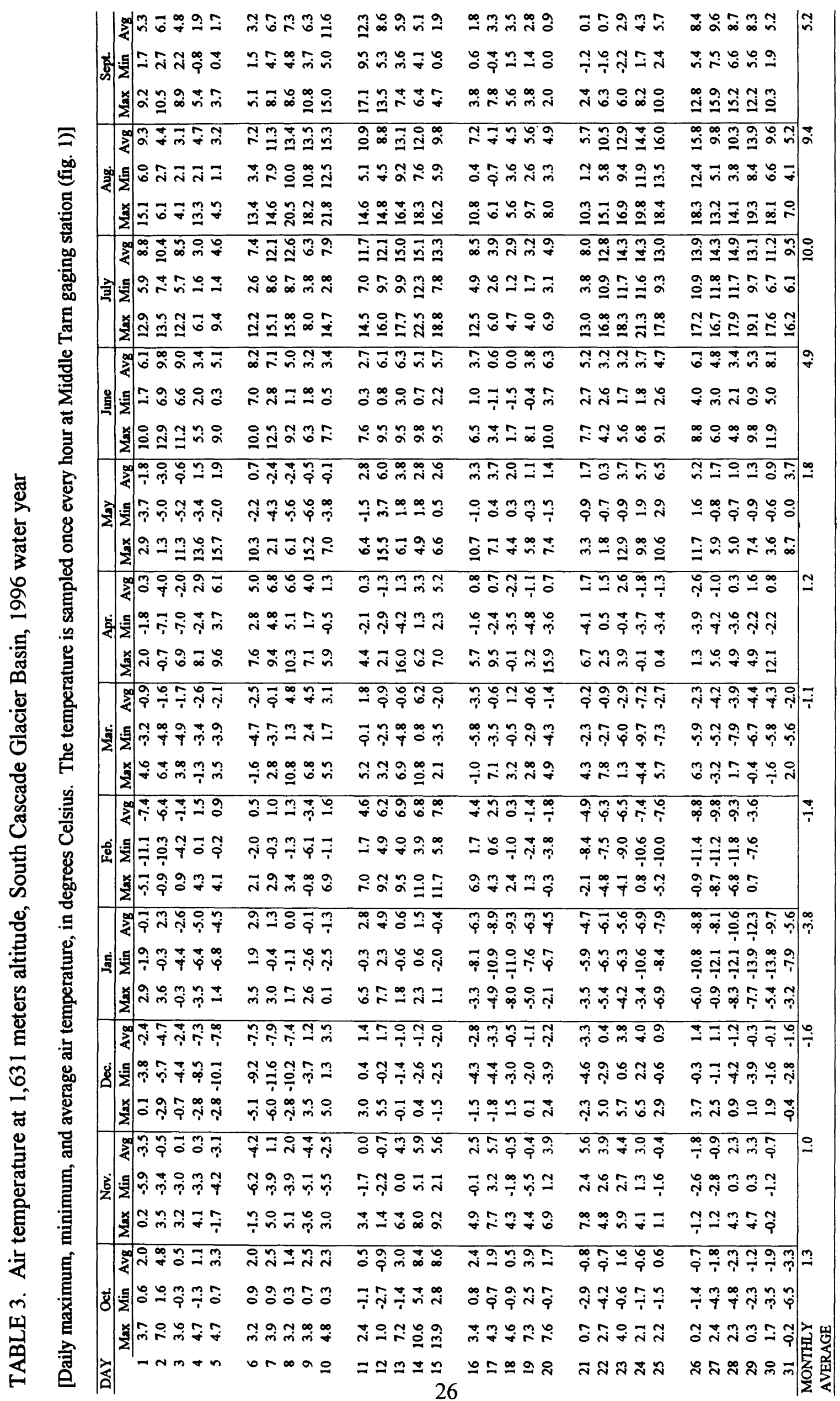



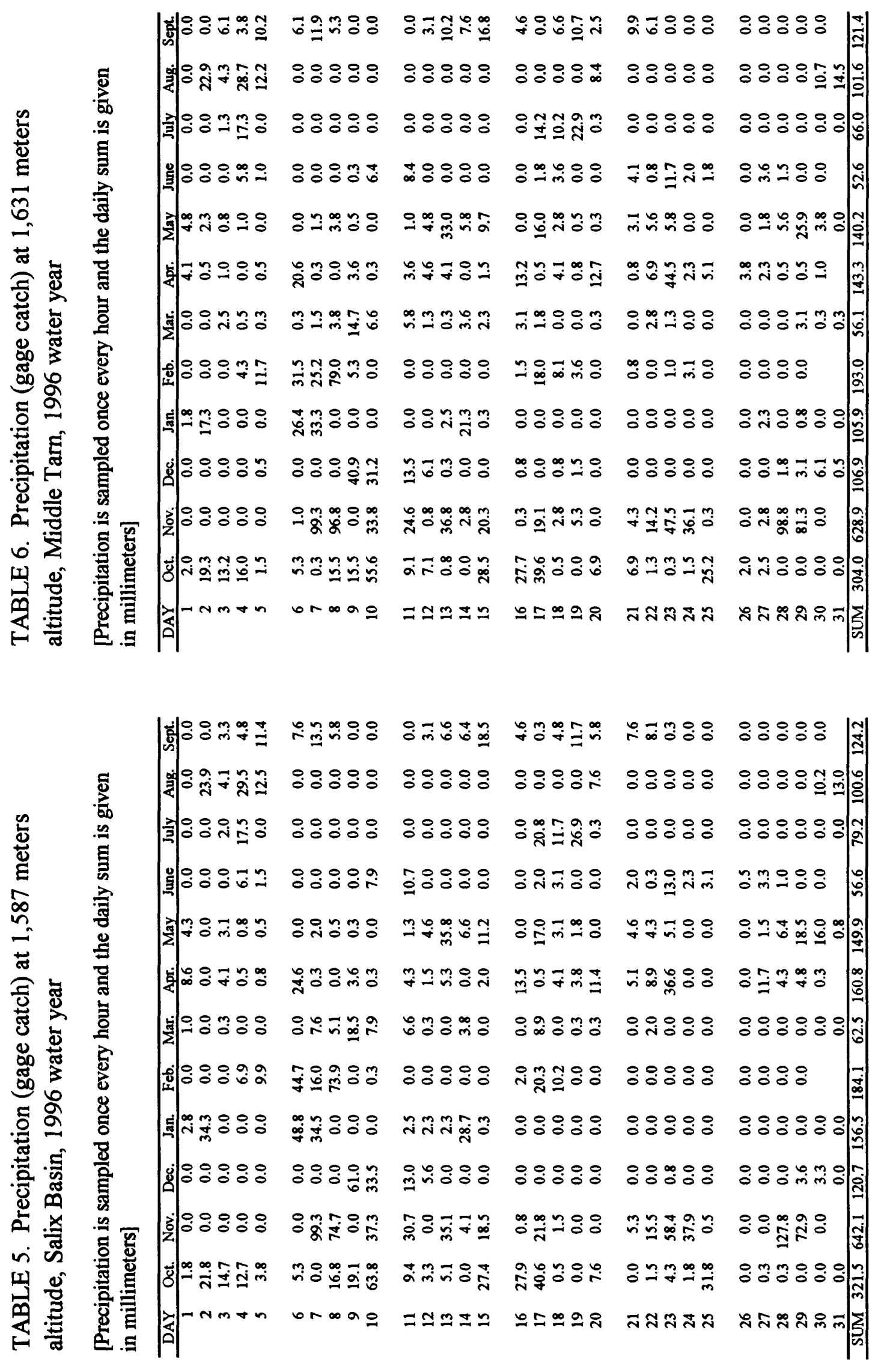
TABLE 7. Snow depths at South Cascade Glacier, May 24, 1996

[Depths, in meters (m) measured with a probe rod; $X, Y$, and $Z$ are local coordinates, \pm 10 meters]

\begin{tabular}{cccc|cccc|cccc|cccc}
\hline $\mathrm{X}$ & $\mathrm{Y}$ & $\mathrm{Z}$ & $\begin{array}{c}\text { Snow } \\
\text { depth } \\
(\mathrm{m})\end{array}$ & $\mathrm{X}$ & $\mathrm{Y}$ & $\mathrm{Z}$ & $\begin{array}{c}\text { Snow } \\
\text { depth } \\
(\mathrm{m})\end{array}$ & $\mathrm{X}$ & $\mathrm{Y}$ & $\mathrm{Z}$ & $\begin{array}{c}\text { Snow } \\
\text { depth } \\
(\mathrm{m})\end{array}$ & $\mathrm{X}$ & $\mathrm{Y}$ & $\mathrm{Z}$ & $\begin{array}{c}\text { Snow } \\
\text { depth } \\
(\mathrm{m})\end{array}$ \\
\hline 2851 & 1803 & 2074 & 6.59 & 2128 & 2043 & 1952 & 6.12 & 2126 & 2743 & 1853 & 5.10 & 1648 & 3088 & 1811 & 3.97 \\
2788 & 1731 & 2065 & 6.61 & 2097 & 2122 & 1945 & 6.28 & 1851 & 2684 & 1856 & 5.78 & 1630 & 3155 & 1793 & 3.22 \\
2721 & 1694 & 2057 & 6.86 & 2061 & 2192 & 1939 & 6.26 & 1785 & 2673 & 1859 & 6.00 & 1619 & 3223 & 1770 & 5.09 \\
2650 & 1662 & 2052 & 6.79 & 2043 & 2249 & 1932 & 5.75 & 1722 & 2670 & 1860 & 6.01 & 1637 & 3290 & 1750 & 4.36 \\
2571 & 1645 & 2044 & 7.29 & 2006 & 2320 & 1923 & 6.42 & 1654 & 2662 & 1861 & 6.27 & 1673 & 3352 & 1733 & 4.12 \\
2494 & 1668 & 2036 & 7.02 & 1983 & 2394 & 1910 & 5.78 & 1882 & 2739 & 1849 & 5.70 & 1707 & 3358 & 1732 & 3.40 \\
2427 & 1709 & 2028 & 7.68 & 1964 & 2465 & 1883 & 6.83 & 1846 & 2781 & 1848 & 5.50 & 1732 & 3412 & 1715 & 4.82 \\
2357 & 1748 & 2017 & 8.00 & 1950 & 2534 & 1871 & 6.15 & 1809 & 2826 & 1848 & 5.50 & 1764 & 3447 & 1695 & 3.96 \\
2289 & 1792 & 2006 & 6.40 & 1933 & 2611 & 1862 & 5.60 & 1773 & 2871 & 1842 & 5.65 & 1792 & 3488 & 1681 & 3.02 \\
2232 & 1847 & 1993 & 6.99 & 1925 & 2691 & 1853 & 5.73 & 1737 & 2918 & 1839 & 5.80 & 1814 & 3534 & 1669 & 1.96 \\
2188 & 1903 & 1975 & 6.95 & 1991 & 2712 & 1847 & 5.61 & 1702 & 2970 & 1832 & 5.38 & 1820 & 3582 & 1660 & 1.15 \\
2153 & 1969 & 1961 & 6.45 & 2057 & 2731 & 1849 & 5.28 & 1672 & 3027 & 1823 & 5.73 & 1827 & 3644 & 1642 & 1.03 \\
\hline
\end{tabular}

TABLE 8. Snow density at 1,618 meters altitude, in South Cascade Glacier Basin, May 24, 1996

[Measured with a snow tube that penetrated the entire snowpack in one sample. The distance between sample locations was about $15 \mathrm{~m}$. WE, water equivalent]

\begin{tabular}{ccc}
\hline Sample & $\begin{array}{c}\text { Depth } \\
\text { (meters) }\end{array}$ & $\begin{array}{c}\text { WE } \\
\text { (meters) }\end{array}$ \\
\hline East end & 1.80 & 0.97 \\
2 & 2.03 & 1.17 \\
3 & 1.70 & .91 \\
4 & 1.30 & - \\
5 & 1.32 & - \\
6 & 1.50 & - \\
7 & 1.42 & - \\
West end & 1.09 & - \\
\hline Average depth $=1.52 \mathrm{~m}$ & \\
Average WE $=0.84 \mathrm{~m}$ & \\
Average density $=0.55$ &
\end{tabular}

TABLE 9. Snow density on South Cascade Glacier, at 1,842 meters altitude, May 24, 1996

[Measured in a snow pit, through the entire thickness of the snow, at local $X=1922, Y=2699, Z=1842$ meters. Diameter of snow tube used in pit $=\mathbf{0 . 0 7 2 3}$ meters, of coring augur $=0.0763$ meters $]$

\begin{tabular}{cccc}
\hline $\begin{array}{c}\text { Sample } \\
\text { bottom } \\
\begin{array}{c}\text { depth } \\
\text { (meters) }\end{array}\end{array}$ & $\begin{array}{c}\text { Sample } \\
\text { length } \\
\text { (meters) }\end{array}$ & $\begin{array}{c}\text { Mass } \\
\text { (kilograms) }\end{array}$ & Density \\
\hline 0.45 & 0.45 & 0.765 & 0.41 \\
.90 & .45 & .760 & .41 \\
1.34 & .44 & .815 & .45 \\
Begin using coring auger & & \\
1.82 & .48 & 1.060 & .48 \\
2.13 & .31 & .615 & .43 \\
2.30 & .17 & .385 & .50 \\
2.37 & .07 & .250 & .78 \\
2.56 & .19 & .410 & .47 \\
2.82 & .26 & .575 & .48 \\
2.88 & .06 & .175 & .64 \\
3.86 & .86 & 2.045 & .53 \\
4.40 & .62 & 1.515 & .54 \\
4.98 & .58 & 1.565 & .55 \\
5.59 & .61 & 1.580 & .52 \\
5.90 & .17 & .460 & .60 \\
\hline Total water equivalent $=2.98$ meters \\
Average density $=0.504$ & & \\
\multicolumn{4}{l}{}
\end{tabular}


TABLE 10. Stake and late season core measurements at South Cascade Glacier in the 1996 balance year

[Surface material may be snow (s) or ice (i); density estimate based on interpolation between measurements made in early May. Balance is the gain or loss of material, referenced to the previous year's melt horizon, in water content. Local X, Y, and Z coordinates (in meters) given for each stake. 1996 stake locations shown on fig. 1. Core locations shown on fig. 13]

\begin{tabular}{|c|c|c|c|c|c|c|c|c|c|}
\hline Date & $\begin{array}{l}\text { Surface } \\
\text { material }\end{array}$ & $\begin{array}{c}\text { Depth } \\
\text { (meters) }\end{array}$ & Density & $\begin{array}{l}\text { Balance } \\
\text { (meters) }\end{array}$ & Date & $\begin{array}{c}\text { Surface } \\
\text { material }\end{array}$ & $\begin{array}{c}\text { Depth } \\
\text { (meters) }\end{array}$ & Density & $\begin{array}{l}\text { Balance } \\
\text { (meters) }\end{array}$ \\
\hline Stake 1 & \multicolumn{4}{|c|}{$[X=2857, Y=1779, Z=2068]$} & Stake 5-96 & \multicolumn{4}{|c|}{$[X=1715, Y=3484, Z=1679]$} \\
\hline May 24 & $\mathbf{s}$ & 6.59 & 0.50 & 3.30 & June 14 & $\mathbf{s}$ & 2.23 & 0.55 & 1.23 \\
\hline June 14 & $\mathbf{s}$ & 5.96 & .53 & 3.16 & July 15 & $\mathbf{s}$ & .20 & .57 & .11 \\
\hline July 15 & $\mathbf{s}$ & 4.70 & .57 & 2.68 & Sept. 10 & i & -3.98 & .90 & -3.58 \\
\hline Sept. 10 & $\mathbf{s}$ & 2.00 & .60 & 1.20 & Minimum & $\mathrm{i}$ & -4.79 & .90 & -4.31 \\
\hline Oct. 9 & $\mathbf{s}$ & 1.57 & .60 & .94 & & & & & \\
\hline \multirow{2}{*}{ Minimum* } & $\mathbf{s}$ & 1.57 & .60 & .94 & Stake 2-94 & $X=181$ & $2, Y=28$ & $312, Z=18$ & 833] \\
\hline & & & & & Minimum & $\mathrm{i}$ & -0.23 & 0.90 & -0.21 \\
\hline Stake 2-96 & \multicolumn{4}{|c|}{$[X=1922, Y=2699, Z=1842]$} & & & & & \\
\hline May 24 & $\mathbf{s}$ & 5.90 & 0.50 & 2.95 & Stake 2-95 & \multicolumn{4}{|c|}{$[X=1816, Y=2891, Z=1828]$} \\
\hline June 14 & $\mathbf{s}$ & 5.11 & .53 & 2.71 & Minimum & $\mathrm{i}$ & -0.03 & 0.90 & -0.03 \\
\hline July 15 & $\mathbf{s}$ & 3.51 & .57 & 2.00 & & & & & \\
\hline Sept. 10 & $\mathbf{s}$ & .55 & .60 & .33 & \multicolumn{5}{|c|}{ Core $[X=2403 \mathrm{Y}=1706, Z=2024]$} \\
\hline Oct. 9 & $\mathrm{i}$ & .00 & .90 & .00 & Minimum & $\mathbf{s}$ & 2.68 & 0.60 & 1.61 \\
\hline \multirow[t]{2}{*}{ Minimum } & $\mathrm{i}$ & .00 & .90 & .00 & & & & & \\
\hline & & & & & \multicolumn{5}{|c|}{ Core $[X=2198, Y=1816, Z=1998]$} \\
\hline Stake 3-96 & \multicolumn{4}{|c|}{$[X=1688, Y=3302, Z=1741]$} & Minimum & $\mathbf{S}$ & 1.81 & 0.60 & 1.09 \\
\hline May 24 & $\mathbf{s}$ & 3.96 & 0.51 & 2.02 & & & & & \\
\hline June 15 & $\mathbf{s}$ & 3.06 & .55 & 1.68 & Core $[X=$ & $=2087, \mathrm{Y}=$ & $=2020, Z=$ & $=1957]$ & \\
\hline Sept. 10 & $\mathbf{i}$ & -2.35 & .90 & -2.12 & Minimum & $\mathbf{s}$ & 1.00 & 0.60 & 0.60 \\
\hline \multirow[t]{2}{*}{ Mimimum } & $\mathbf{i}$ & -2.92 & .90 & -2.63 & & & & & \\
\hline & & & & & Core $[X=$ & $=1994, Y=$ & $=2418, \mathrm{Z}=$ & $=19111$ & \\
\hline Stake 4-95 & \multicolumn{4}{|c|}{$[X=1831, Y=3636, Z=1627]$} & Minimum & $\underline{s}$ & 0.87 & 0.60 & 0.52 \\
\hline May 21 & $\mathbf{s}$ & 1.15 & 0.53 & 0.61 & & & & & \\
\hline June 14 & $\mathbf{s}$ & .19 & .55 & .10 & & & & & \\
\hline Stake 4-96 & \multicolumn{4}{|c|}{$[X=1842, Y=3585, Z=1636]$} & & & & & \\
\hline June 14 & $\overline{\mathbf{i}}$ & 0.00 & 0.90 & 0.00 & & & & & \\
\hline July 15 & $\mathbf{i}$ & -1.98 & .90 & -1.78 & & & & & \\
\hline Sept. 10 & $\mathrm{i}$ & -6.14 & .90 & -5.53 & & & & & \\
\hline Oct. 9 & i & -6.96 & .90 & -6.26 & & & & & \\
\hline Minimum & i & -7.16 & .90 & -6.44 & & & & & \\
\hline
\end{tabular}


[Surface altitude $(Z)$, in meters above National Geodetic Vertical Datum of 1929, was measured near the nominal point for each grid cell. Coordinates $\mathrm{X}$ and $\mathrm{Y}$ are local. The tenths of meters are marginally significant. Grid points with an * are from the 1995 altitude grid]

\begin{tabular}{|c|c|c|c|c|c|c|c|c|c|c|c|}
\hline$X$ & $\mathrm{Y}$ & $Z$ & $X$ & $\mathrm{Y}$ & $Z$ & $X$ & $Y$ & $Z$ & $X$ & $\mathbf{Y}$ & $Z$ \\
\hline 1670.2 & 3700.0 & 1637.8 & 1770.0 & 2899.8 & 1841.2 & * 1870.7 & 2400.4 & 1895.5 & $* 2172.0$ & 1800.7 & 1991.6 \\
\hline 1669.8 & 3599.1 & 1662.0 & 1569.5 & 2899.4 & 1843.5 & * 1769.4 & 2401.1 & 1891.5 & * 2270.6 & 1799.2 & 2006.1 \\
\hline 1770.6 & 3599.6 & 1651.4 & 1569.9 & 2799.9 & 1850.8 & * 1669.8 & 2398.8 & 1889.3 & * 2370.8 & 1802.6 & 2020.1 \\
\hline 1870.2 & 3599.3 & 1635.7 & 1869.8 & 2799.7 & 1846.8 & * 1571.6 & 2401.1 & 1896.2 & * 2470.4 & 1799.0 & 2028.4 \\
\hline 1869.8 & 3500.6 & 1656.5 & 1968.8 & 2798.0 & 1845.8 & * 1571.9 & 2300.8 & 1927.4 & * 2571.9 & 1799.4 & 2037.6 \\
\hline 1769.4 & 3499.6 & 1677.1 & 2070.6 & 2798.7 & 1842.5 & $* 1670.9$ & 2301.9 & 1908.7 & *2671.1 & 1801.9 & 2054.8 \\
\hline 1668.4 & 3499.0 & 1690.3 & 2169.9 & 2799.6 & 1836.6 & $* 1771.1$ & 2300.6 & 1902.0 & * 2770.8 & 1798.2 & 2067.0 \\
\hline 1571.2 & 3500.5 & 1677.8 & 2269.8 & 2799.7 & 1838.4 & * 1869.7 & 2300.7 & 1908.6 & * 2871.9 & 1799.7 & 2080.1 \\
\hline 1569.7 & 3399.8 & 1717.9 & 2369.8 & 2699.1 & 1871.7 & * 1970.7 & 2300.6 & 1923.2 & * 2970.9 & 1800.4 & 2077.0 \\
\hline 1669.9 & 3399.6 & 1718.6 & 2068.2 & 2699.9 & 1848.2 & $* 2070.0$ & 2300.3 & 1927.9 & * 3069.4 & 1798.9 & 2081.9 \\
\hline 1770.0 & 3399.7 & 1704.5 & 1869.3 & 2700.1 & 1852.6 & $* 2171.1$ & 2300.9 & 1931.5 & *3169.6 & 1799.4 & 2091.6 \\
\hline 1869.3 & 3399.5 & 1676.9 & 1771.2 & 2699.3 & 1857.5 & $* 2271.1$ & 2301.6 & 1941.4 & * 3168.3 & 1700.8 & 2120.7 \\
\hline 2070.6 & 3399.2 & 1702.1 & 1670.2 & 2699.5 & 1858.5 & * 2370.4 & 2301.1 & 1944.3 & * 3070.5 & 1701.5 & 2100.8 \\
\hline 2169.4 & 3299.0 & 1728.6 & 1569.3 & 2599.5 & 1865.9 & * 2469.8 & 2300.9 & 1957.6 & * 2968.7 & 1699.1 & 2079.9 \\
\hline 2070.2 & 3300.0 & 1735.7 & 2269.0 & 2599.0 & 1890.1 & * 2569.6 & 2301.2 & 2005.2 & * 2871.4 & 1702.4 & 2077.0 \\
\hline 1970.4 & 3300.3 & 1739.0 & 2169.0 & 2499.9 & 1900.6 & $* 2472.9$ & 2201.2 & 1963.4 & $* 2770.7$ & 1701.2 & 2063.6 \\
\hline 1770.3 & 3299.2 & 1737.1 & * 1472.0 & 2899.7 & 1848.9 & $* 2371.1$ & 2200.1 & 1952.2 & $* 2670.9$ & 1700.1 & 2050.0 \\
\hline 1670.2 & 3300.4 & 1744.6 & * 1671.5 & 2901.7 & 1843.0 & * 2271.0 & 2198.5 & 1949.3 & * 2570.1 & 1701.4 & 2035.7 \\
\hline 1569.5 & 3300.0 & 1747.3 & * 2369.7 & 2898.9 & 1842.4 & $* 2171.2$ & 2198.7 & 1942.0 & * 2469.7 & 1700.1 & 2031.6 \\
\hline 1470.8 & 3297.8 & 1752.3 & * 2371.9 & 2799.8 & 1855.3 & * 2068.2 & 2200.5 & 1937.5 & * 2368.5 & 1700.7 & 2025.4 \\
\hline 1470.8 & 3199.7 & 1780.8 & * 1771.5 & 2798.8 & 1848.9 & $* 1970.0$ & 2199.9 & 1930.0 & * 2269.7 & 1699.9 & 2014.0 \\
\hline 1569.7 & 3199.5 & 1775.7 & * 1670.1 & 2798.7 & 1850.7 & * 1869.5 & 2200.7 & 1920.7 & $* 2171.2$ & 1698.8 & 2004.1 \\
\hline 1669.8 & 3199.8 & 1779.0 & * 1472.4 & 2798.7 & 1861.5 & $* 1770.0$ & 2200.0 & 1930.4 & $* 2069.7$ & 1701.3 & 1998.0 \\
\hline 1769.9 & 3199.9 & 1790.0 & * 1469.2 & 2700.6 & 1871.7 & * 1669.3 & 2200.0 & 1930.5 & * 1971.0 & 1698.8 & 2007.7 \\
\hline 1869.6 & 3199.5 & 1799.3 & * 1571.6 & 2701.5 & 1859.1 & * 1768.9 & 2099.9 & 1943.2 & * 2071.0 & 1600.6 & 2028.5 \\
\hline 1968.7 & 3199.1 & 1799.7 & * 1969.9 & 2700.3 & 1851.7 & * 1872.0 & 2099.1 & 1943.0 & $* 2170.0$ & 1601.0 & 2019.4 \\
\hline 2068.8 & 3199.7 & 1780.5 & * 2171.2 & 2701.5 & 1848.1 & * 1969.5 & 2099.0 & 1942.7 & * 2270.6 & 1600.5 & 2022.2 \\
\hline 2169.2 & 3199.0 & 1772.1 & * 2271.0 & 2699.5 & 1859.7 & * 2070.5 & 2100.8 & 1945.5 & * 2370.4 & 1599.4 & 2027.5 \\
\hline 2269.1 & 3099.2 & 1793.0 & $* 2370.9$ & 2601.0 & 1902.4 & $* 2170.5$ & 2098.8 & 1950.2 & * 2470.4 & 1599.8 & 2038.3 \\
\hline 2169.3 & 3099.9 & 1813.5 & * 2169.0 & 2600.2 & 1871.6 & * 2270.9 & 2098.4 & 1953.4 & * 2570.9 & 1599.2 & 2045.5 \\
\hline 2070.1 & 3100.2 & 1821.8 & * 2070.1 & 2601.2 & 1862.2 & * 2569.8 & 2097.9 & 2000.9 & * 2670.1 & 1600.3 & 2056.3 \\
\hline 1971.0 & 3099.6 & 1825.7 & * 1969.9 & 2601.0 & 1861.7 & * 2469.7 & 2101.7 & 1970.8 & * 2769.1 & 1601.3 & 2070.3 \\
\hline 1870.0 & 3099.3 & 1824.6 & * 1870.2 & 2599.8 & 1864.6 & * 2371.8 & 2098.3 & 1958.1 & *2869.6 & 1601.3 & 2081.8 \\
\hline 1770.8 & 3099.5 & 1816.5 & * 1769.7 & 2599.4 & 1867.4 & * 1871.5 & 2000.1 & 1966.0 & * 2972.2 & 1602.7 & 2099.4 \\
\hline 1669.2 & 3098.6 & 1809.1 & * 1671.3 & 2599.0 & 1868.8 & * 1969.6 & 2000.3 & 1959.6 & * 3069.5 & 1602.8 & 2125.1 \\
\hline 1570.4 & 3100.0 & 1808.0 & $* 1470.7$ & 2499.7 & 1898.6 & * 2070.4 & 2001.2 & 1959.2 & * 2872.6 & 1498.2 & 2100.9 \\
\hline 1470.1 & 3099.5 & 1813.4 & * 1571.0 & 2501.2 & 1879.6 & * 2169.4 & 2000.5 & 1956.8 & * 2770.6 & 1500.6 & 2075.0 \\
\hline 1469.7 & 2999.7 & 1836.9 & $* 1670.1$ & 2500.6 & 1878.8 & * 2270.9 & 1999.1 & 1956.7 & * 2671.3 & 1501.0 & 2064.8 \\
\hline 1569.9 & 2999.4 & 1827.6 & * 1771.6 & 2499.0 & 1877.9 & * 2370.3 & 2000.3 & 1967.2 & *2571.9 & 1501.6 & 2050.2 \\
\hline 1669.7 & 2999.7 & 1827.1 & * 1870.7 & 2500.3 & 1877.8 & * 2470.6 & 2002.4 & 1981.7 & $* 2470.9$ & 1499.6 & 2046.1 \\
\hline 1769.2 & 3001.4 & 1831.4 & * 1969.6 & 2500.0 & 1880.7 & $* 2470.8$ & 1899.6 & 2008.1 & * 2369.9 & 1501.0 & 2036.5 \\
\hline 1868.7 & 2999.5 & 1838.1 & * 2070.1 & 2500.0 & 1885.7 & * 2369.8 & 1901.0 & 1992.1 & * 2272.3 & 1498.3 & 2037.7 \\
\hline 1969.6 & 2999.1 & 1837.4 & * 2271.6 & 2499.3 & 1914.2 & * 2271.9 & 1900.0 & 1984.9 & * 2168.6 & 1497.2 & 2042.7 \\
\hline 2069.6 & 2998.7 & 1835.0 & *2369.6 & 2499.6 & 1926.1 & $* 2170.1$ & 1901.8 & 1972.1 & * 2270.9 & 1399.9 & 2074.8 \\
\hline 2169.8 & 2999.0 & 1829.4 & * 2470.6 & 2400.0 & 1961.4 & * 2068.3 & 1901.4 & 1970.6 & * 2371.7 & 1400.6 & 2060.3 \\
\hline 2270.1 & 2999.3 & 1828.8 & $* 2371.5$ & 2401.2 & 1941.9 & * 1969.5 & 1897.9 & 1974.5 & * 2471.7 & 1400.9 & 2055.2 \\
\hline 2270.2 & 2901.5 & 1830.5 & * 2269.1 & 2401.5 & 1931.8 & $* 1868.1$ & 1900.8 & 1989.4 & $* 2569.1$ & 1400.0 & 2059.4 \\
\hline 2169.3 & 2899.0 & 1837.3 & $* 2169.9$ & 2401.2 & 1917.1 & * 1869.4 & 1800.1 & 2007.4 & * 2670.4 & 1400.6 & 2089.2 \\
\hline 2068.5 & 2899.9 & 1840.0 & * 2070.5 & 2401.3 & 1910.7 & * 1970.1 & 1801.7 & 1995.3 & *2771.1 & 1401.1 & 2109.9 \\
\hline 1971.3 & 2899.9 & 1844.4 & • 1969.1 & 2399.6 & 1907.2 & $* 2070.0$ & 1800.2 & 1983.8 & & & \\
\hline 1870.4 & 2900.9 & 1843.1 & & & & & & & & & \\
\hline
\end{tabular}




\begin{tabular}{|c|c|c|c|c|c|c|c|}
\hline & & 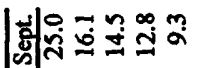 & 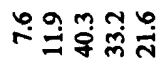 & 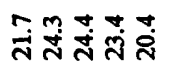 & $\overrightarrow{9} \infty \min ^{\circ}$ & 욱영 & $\stackrel{\pi}{i}$ \\
\hline & $\frac{8}{\pi}$ & 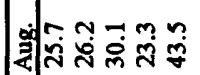 & ซี่ & 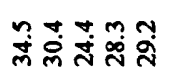 & 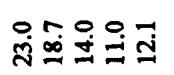 & 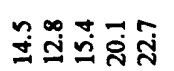 & 迎 \\
\hline & : & 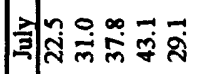 & 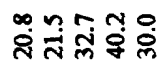 & 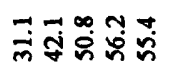 & 芦 & 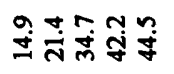 & 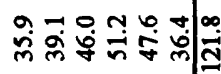 \\
\hline & 임 & 䒺 & 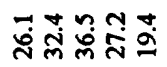 & 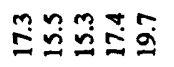 & $\stackrel{n}{2} \tilde{=} \cong \infty$ & 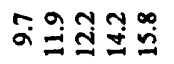 & $\stackrel{m}{\infty} \underset{\infty}{\infty} \stackrel{\infty}{=} \underset{\infty}{\infty}$ \\
\hline 8 & 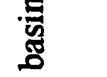 & 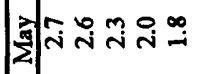 & モュュْ & क्षे & 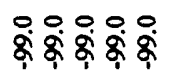 & क्षे우울 & - \\
\hline & 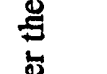 & 安过 & 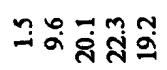 & 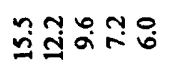 & ดे & 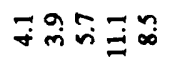 & 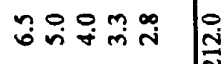 \\
\hline & 8 & 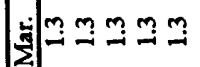 & 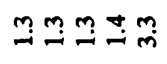 & ติ & & ב & 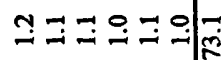 \\
\hline$=$ & त्d & - & क्ष क्षेक्ष & 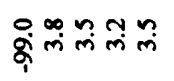 & 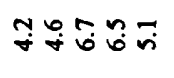 & 开 & 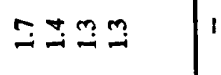 \\
\hline 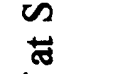 & மூర & 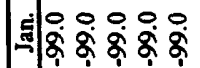 & 웅ํㅇ & $8 \%$ & क्षं & $\stackrel{\circ}{8}$ & क्ष \\
\hline 9 & 䍐 & | & 웅웅영 & क웅영웅 & 8웅 & क्ष & 웅우 \\
\hline &. & $\mid$ & 궁용영 & 영영영 & 웅영영영 & 웅영영영 & 웅웅ㅇㅇㅇㅇㅇ \\
\hline 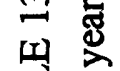 & $\stackrel{0}{3}$ & 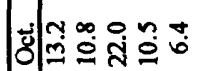 & $\stackrel{\infty}{\rightarrow} \stackrel{+}{+} \stackrel{+}{+} \stackrel{+}{\dot{q}}$ & $\Xi \underset{n}{n}$ & กิ๊ & 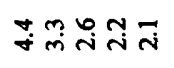 & 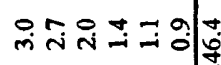 \\
\hline 《 & 疍 & 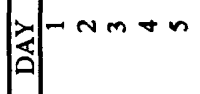 & & & & & in \\
\hline
\end{tabular}

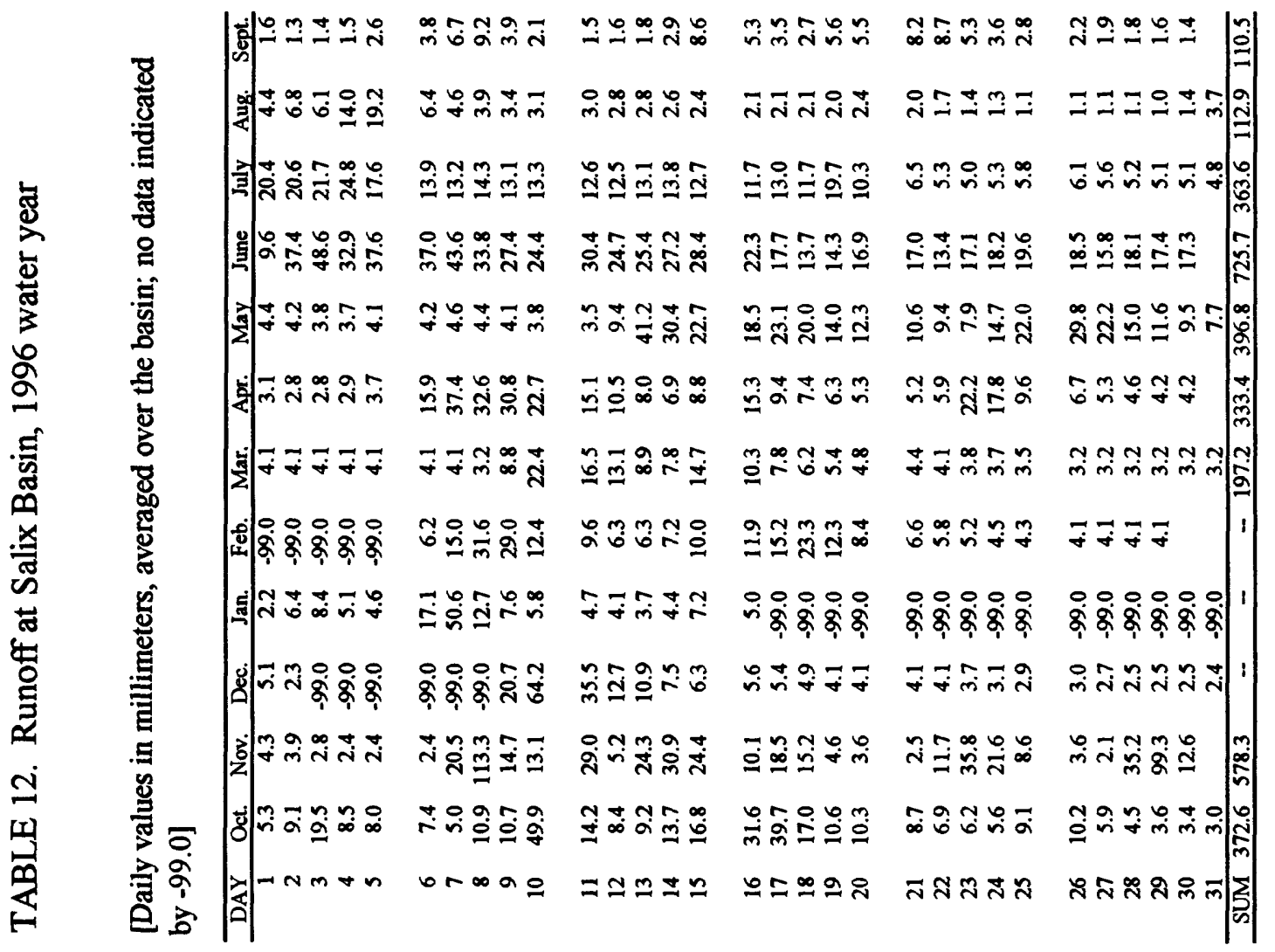


TABLE 14. Runoff at Middle Tarn Basin, 1996 water year

[Daily values in millimeters, averaged over the basin. A - 99.0 indicates no data]

\begin{tabular}{|c|c|c|c|c|c|c|c|c|c|c|c|c|}
\hline DAY & Oct. & Nov. & Dec. & Jan. & Feb. & Mar. & Apr. & May & June & July & Aug. & Sept. \\
\hline 1 & 23.4 & 8.7 & 30.3 & -99.0 & -99.0 & -99.0 & -99.0 & -99.0 & 3.4 & 24.4 & 24.6 & 20.0 \\
\hline 2 & 38.1 & 8.5 & 36.4 & -99.0 & -99.0 & -99.0 & -99.0 & -99.0 & 11.1 & 30.7 & 29.1 & 16.2 \\
\hline 3 & 36.3 & 8.2 & -99.0 & -99.0 & -99.0 & -99.0 & -99.0 & -99.0 & 23.6 & 35.1 & 26.7 & 16.6 \\
\hline 4 & 20.7 & 8.3 & -99.0 & -99.0 & -99.0 & -99.0 & -99.0 & -99.0 & 22.8 & 35.6 & 26.4 & 12.3 \\
\hline 5 & 17.2 & 8.6 & -99.0 & -99.0 & -99.0 & -99.0 & -99.0 & -99.0 & 21.0 & 22.4 & 35.4 & 8.8 \\
\hline 6 & 15.9 & 8.3 & -99.0 & -99.0 & -99.0 & -99.0 & -99.0 & -99.0 & 22.7 & 18.7 & 20.5 & 7.9 \\
\hline 7 & 14.7 & 20.8 & -99.0 & -99.0 & -99.0 & -99.0 & -99.0 & -99.0 & 29.2 & 24.3 & 20.4 & 22.3 \\
\hline 8 & 15.9 & 118.8 & -99.0 & -99.0 & -99.0 & -99.0 & -99.0 & -99.0 & 26.9 & 36.1 & 23.5 & 46.4 \\
\hline 9 & 14.7 & 62.4 & -99.0 & -99.0 & -99.0 & -99.0 & -99.0 & -99.0 & 20.9 & 33.8 & 27.6 & 26.3 \\
\hline 10 & 31.3 & 39.2 & -99.0 & -99.0 & -99.0 & -99.0 & -99.0 & -99.0 & 15.6 & 26.8 & 34.5 & 21.5 \\
\hline 11 & 17.7 & 34.9 & -99.0 & -99.0 & -99.0 & -99.0 & -99.0 & -99.0 & 14.4 & 33.8 & 35.3 & 25.8 \\
\hline 12 & 13.4 & 21.6 & -99.0 & -99.0 & -99.0 & -99.0 & -99.0 & 16.0 & 13.1 & 42.1 & 27.8 & 27.3 \\
\hline 13 & 13.6 & 41.6 & -99.0 & -99.0 & -99.0 & -99.0 & -99.0 & 20.5 & 14.3 & 50.2 & 27.3 & 25.0 \\
\hline 14 & 33.4 & 73.0 & -99.0 & -99.0 & -99.0 & -99.0 & -99.0 & 19.6 & 16.3 & 50.5 & 32.0 & 22.6 \\
\hline 15 & 35.0 & 50.2 & -99.0 & -99.0 & -99.0 & -99.0 & -99.0 & 18.3 & 17.4 & 51.2 & 28.2 & 18.0 \\
\hline 16 & 44.4 & 35.8 & -99.0 & -99.0 & -99.0 & -99.0 & -99.0 & 16.7 & 16.7 & 45.6 & 22.5 & 10.1 \\
\hline 17 & 38.8 & 32.0 & -99.0 & -99.0 & -99.0 & -99.0 & -99.0 & 18.8 & 12.9 & 34.4 & 18.5 & 7.2 \\
\hline 18 & 26.4 & 38.8 & -99.0 & -99.0 & -99.0 & -99.0 & -99.0 & 17.6 & 9.9 & 22.5 & 13.8 & 6.1 \\
\hline 19 & 18.6 & 23.4 & -99.0 & -99.0 & -99.0 & -99.0 & -99.0 & 14.7 & 8.2 & 18.7 & 12.2 & 11.8 \\
\hline 20 & 16.0 & 19.4 & -99.0 & -99.0 & -99.0 & -99.0 & -99.0 & 13.4 & 8.9 & 15.6 & 16.7 & 8.3 \\
\hline 21 & 14.2 & 16.6 & -99.0 & -99.0 & -99.0 & -99.0 & -99.0 & 13.2 & 10.9 & 16.6 & 16.4 & 6.2 \\
\hline 22 & 12.5 & 26.5 & -99.0 & -99.0 & -99.0 & -99.0 & -99.0 & -99.0 & 12.3 & 28.8 & 15.0 & 4.9 \\
\hline 23 & 11.6 & 57.5 & -99.0 & -99.0 & -99.0 & -99.0 & -99.0 & -99.0 & 12.6 & 37.0 & 21.6 & 3.9 \\
\hline 24 & 11.0 & 43.0 & -99.0 & -99.0 & -99.0 & -99.0 & -99.0 & 7.0 & 14.4 & 45.2 & 23.9 & 3.4 \\
\hline 25 & 11.3 & 27.4 & -99.0 & -99.0 & -99.0 & -99.0 & -99.0 & 7.1 & 16.0 & 38.6 & 26.6 & 3.1 \\
\hline 26 & 13.1 & 20.8 & -99.0 & -99.0 & -99.0 & -99.0 & -99.0 & 8.6 & 17.3 & 36.5 & 31.6 & 5.0 \\
\hline 27 & 10.9 & 17.5 & -99.0 & -99.0 & -99.0 & -99.0 & -99.0 & 8.5 & 16.9 & 41.3 & 30.5 & 7.9 \\
\hline 28 & 10.1 & 36.4 & -99.0 & -99.0 & -99.0 & -99.0 & -99.0 & 6.3 & 18.7 & 47.8 & 34.7 & 7.7 \\
\hline 29 & 9.6 & 124.4 & -99.0 & -99.0 & -99.0 & -99.0 & -99.0 & 5.0 & 17.4 & 50.6 & 39.9 & 8.8 \\
\hline 30 & 9.5 & 51.6 & -99.0 & -99.0 & & -99.0 & -99.0 & 3.9 & 18.8 & 43.0 & 43.7 & 10.4 \\
\hline 31 & 9.0 & & -99.0 & -99.0 & & -99.0 & & 3.3 & & 31.2 & 42.2 & \\
\hline SUM & 608.4 & 84.2 & -- & -- & - & -- & -- & -- & 484.5 & 068.6 & 828.6 & 421.9 \\
\hline
\end{tabular}


TABLE 15. Values used to interpolate snow depth at any altitude on South Cascade Glacier, 1996 [values in meters]

\begin{tabular}{cc}
\hline Altitude & Snow depth \\
\hline 1629 & 0.4 \\
1644 & 1.2 \\
1661 & 1.8 \\
1679 & 2.6 \\
1703 & 3.2 \\
1730 & 3.9 \\
1761 & 4.6 \\
1801 & 5.2 \\
1851 & 5.8 \\
1904 & 6.3 \\
1965 & 6.7 \\
2025 & 7.0 \\
2093 & 7.4 \\
2154 & 7.6 \\
\hline
\end{tabular}

TABLE 16. Values used to interpolate net balance at any altitude on South Cascade Glacier, 1996 [values in meters]

\begin{tabular}{cc}
\hline Altitude & Net balance \\
\hline 1628 & -6.92 \\
1643 & -6.27 \\
1657 & -5.63 \\
1672 & -4.97 \\
1688 & -4.35 \\
1705 & -3.67 \\
1720 & -3.06 \\
1738 & -2.44 \\
1757 & -1.84 \\
1778 & -1.22 \\
1805 & -.60 \\
1839 & -.06 \\
1886 & .41 \\
1942 & .78 \\
2001 & 1.05 \\
2065 & 1.28 \\
2127 & 1.44 \\
2190 & 1.57 \\
\hline
\end{tabular}

